\title{
The Corredoiras orthogneiss (NW Iberian Massif): Geochemistry and geochronology of the Paleozoic magmatic suite developed in a peri-Gondwanan arc
}

\author{
P. Andonaegui a,*, P. Castiñeiras ${ }^{\text {a }}$, P. González Cuadra ${ }^{\text {b }}$, R. Arenas ${ }^{a}$, S. Sánchez Martínez a ${ }^{\text {, J. Abati }}{ }^{\text {a }}$, \\ F. Díaz García ${ }^{\mathrm{c}}$, J.R. Martínez Catalán a \\ a Departamento de Petrología y Geoquímica, Instituto de Geología Económica (CSIC), Universidad Complutense de Madrid, 28040 Madrid, Spain \\ b Instituto Geologico y Minero de España, 15703 Santiago de Compostela, Spain \\ ${ }^{c}$ Departamento de Geologia, Universidad de Oviedo, 33005 viedo, Spain \\ aepartamento de Geología, Universidad de Salamanca, 37008 Salamanca, Spain
}

Keywords:

Geochemistry

Geochronology

Metaigneous rocks

Magmatic arc

Northern Gondwana margin

Iberian Massif

\begin{abstract}
A B S T R A C T
The Corredoiras orthogneiss belongs to the intermediate pressure upper units of the Órdenes Complex (Variscan belt, NW Spain), mainly composed by granodioritic orthogneisses, with small bodies of tonalitic orthogneisses, amphibole-rich orthogneisses and metagabbronorites. In this work we study their chemical and isotopic composition, to gain insight into the linkage between plate tectonics and magmatism and to improve the knowledge of the paleogeographic evolution of the European Variscan Belt.

Granodioritic and tonalitic orthogneisses range from intermediate to felsic rocks, with $\mathrm{K}_{2} \mathrm{O} / \mathrm{Na}_{2} \mathrm{O}$ ratios $\approx 1$, typical of calc-alkaline rocks, and high $\mathrm{Na}_{2} \mathrm{O}$ content, characteristic of I-type granites. Metagabbronorites are basic rocks, but some of them are contaminated by interaction with the felsic magmas, showing enrichment in $\mathrm{SiO}_{2}, \mathrm{Na}_{2} \mathrm{O}$ and $\mathrm{K}_{2} \mathrm{O}$. All Corredoiras metaigneous rocks are enriched in large ion lithophile elements (LILE) and light rare earth elements (IREE) relative to high field strength elements (HFSE), resulting in a high LILE/HFSE ratio. These geochemical features are the most characteristic of magmas related to subduction zones; furthermore all orthogneisses display significant negative anomalies in $\mathrm{Ta}, \mathrm{Nb}$ and $\mathrm{Zr}$, which together with their low contents in $\mathrm{Y}$ and $\mathrm{Yb}$ match up with granitoids generated in volcanic arcs or subduction zones. SHRIMP U-Pb zircon dating provides a concordia age of $492 \pm 3 \mathrm{Ma}$. Granodioritic orthogneiss has negative $\varepsilon \mathrm{Nd}_{(492 \mathrm{Ma})}$ values $(-2.2$ to -3.6$)$ and high $\left({ }^{87} \mathrm{Sr} /{ }^{86} \mathrm{Sr}\right)_{\mathrm{i}}$ ratios $(0.707$ to 0.708$)$, on the other hand tonalitic orthogneisses and metagabbronorites have positive $\varepsilon \mathrm{Nd}_{(492 \mathrm{Ma})}(1.0$ to 2.4$)$ and low $\left({ }^{87} \mathrm{Sr} /{ }^{86} \mathrm{Sr}\right)_{\mathrm{i}}(0.703$ to 0.705 ), suggesting that granodioritic orthogneisses have a clear crustal influence in their generation, whereas tonalitic orthogneisses and metagabbros can be related to basic magmas extracted from the mantle or from a basic lower continental crust.

The Corredoiras chemical characteristics permit us to interpret that this rocks were probably generated in an ensialic island arc and may represent a peri-Gondwanan fragment drifted away to open the Rheic Ocean.
\end{abstract}

\section{Introduction}

The basement of the European Variscan Belt is composed of several early Paleozoic crustal fragments. The origin of these pieces has been attributed to tectonic processes that occurred along the northern margin of Gondwana during its protracted geological history involving varied events, such as plate subduction, generation of magmatic arcs and rifting (Martínez Catalán et al., 2009; Matte, 1991; Pin, 1990). The study of the chemical and isotopic composition of igneous rocks in ancient orogens like the European Variscan Belt, where the original geological relationships are extremely reworked, is very

\footnotetext{
* Corresponding author. Tel.: + 3491394 4909; fax: + 34915442535

E-mail address: andonaeg@geo.ucm.es (P. Andonaegui).
}

useful in the reconsuction of paleotectonic environments. Specifically, calc-alkaline affinity rocks, which are mainly generated in mature magmatic arcs, can help us to determine the existence of an ensialic basement in these arcs. This ensialic basement makes possible the appearance of geochemically evolved plutonic rocks, as it occurs in the Izu-Bonin, Cuba or New Britain arc systems, which contain volumetrically important tonalite and granodiorite batholiths (Kawate and Arima, 1998; Marchesi et al., 2007; Rojas-Agramonte et al., 2004; Woodhead et al., 1998). The study area is located in the northwestern region of the Iberian Massif, which preserves one of the best sections of the internal part of the European Variscan Belt, with several allochthonous complexes located in Galicia (Órdenes, Cabo Ortegal and the Malpica-Tui unit) and Portugal (Bragança and Morais). 
In this work, we study the chemical and isotopic composition of the Corredoiras unit, which is part of the intermediate pressure upper units (Díaz García et al., 1999b; González Cuadra, 2007). The metaigneous rocks that form part of the Corredoiras unit, include a varied range of rocks types, dominated by a granodiorite-granite association, with small amounts of tonalite and gabbro. The study of these rock associations is important to gain insight into the linkage between plate tectonics and magmatism and to improve the knowledge of the paleogeographic evolution of the European Variscan Belt.

\section{Geological setting}

The European Variscan Belt is a Devonian-Carboniferous orogen generated during the progressive collision between Gondwana and Iaurussia, and the consequent closure of the Rheic Ocean (Martínez Catalán et al., 2009). The axial zone of the Variscan Belt is characterized by the presence of several allochthonous complexes constituted by exotic terranes with ophiolites and high-P metamorphic rocks (Arenas et al., 1986). These exotic terranes outline the intricate Pangea suture in Europe, which is rootless and it was transported within the allochthonous complexes towards more external regions of the Variscan Belt. In the NW Iberian Massif, five allochthonous complexes are preserved in late synformal structures: three of them outcropping in Galicia (Cabo Ortegal, Órdenes and the Malpica-Tui unit) and two in the Portuguese region of Trás-os-Montes (Bragança and Morais complexes). The Órdenes Complex is the largest one (Fig. 1) and it is constuted by basal, ophiolitic and upper units (Martínez Catalán et al, 2002, 2007).

In the Galician allochthonous complexes it is possible to distinguish several slices with different origins. These slices can be grouped in three sets of units named, from bottom to top: basal, ophiolitic and upper units (Martínez Catalán et al., 2002, 2007). These units converged at the onset of the Variscan Orogeny, and thereafter, during their accretion and exhumation, they were dismembered and thinned, reaching their present configuration as a consequence of late orogenic processes of folding and faulting (Martínez Catalán et al., 2009). As the ophiolitic units are considered to represent a collisional suture (Arenas et al., 2007a; Sánchez Martínez et al., 2007a, $2007 \mathrm{~b}$ ), the basal units are interpreted as the most external continental margin of Gondwana (Abati et al., 2010; Arenas et al., 1995, 1997; Martínez Catalán et al., 1996; Rodríguez et al., 2003), whereas the upper units represent exotic terranes with Gondwanan affinity. These upper units can be divided in two sets with contrasting pressure and temperature conditions; on one hand, the high-pressure and high-temperature units (HP-HT), occupying the lower structural position and, on the other hand, the intermediate pressure units (IP) on top of the orogenic pile (Abati et al., 1999, 2003; Fernández Suárez et al., 2007; Ordoñez Casado et al., 2001).

There is a variety of felsic metaigneous rocks in the basal and the upper units and the study of their chemical and isotopic composition is essential to establish their tectonic setting. This knowledge will contribute to the paleogeographic reconstruction of the different ognized in the allochthonous complexes. For example, in the basal units, two igneous series with different

(Rodríguez Aller, 2005): an older series with calc-alkaline affinity (490-480 Ma; Abati et al., 2010; Díez Fernández et al., 2011; Santos Zalduegui et al., 1995), and a younger series with alkaline-peralkaline composition (480-470 Ma; Díez Fernández et al., 2011; Montero et al., 2009; Rodríguez et al., 2007). This bimodal magmatism and its geochemical characteristics point to a Cambro-Ordovician extensional episode in the most external margin of Gondwana that signals the origin of the Rheic Ocean (Abati et al., 2010; Díez Fernández et al., 2011; Martinez Catalán et al, 2009).

In the upper units there is a wider diversity of igneous rocks, including ultramafic, mafic and felsic types (Arenas et al., 2007b). The ages of magmatism vary between 520 and 500 Ma (Abati et al, 1999, 2007; Castiñeiras et al., 2010; Fernández Suárez et al., 2007; Ordóñez
Casado, 1998; Santos et al., 2002). There are a few studies on the geochemistry of the igneous rocks in the HP-HT units (Galán and Marcos, 1997; Gil lbarguchi et al., 1990; Mendia Aranguren, 2000) and the mafic rocks in the IP units (Andonaegui et al., 2002); however, no geochemical study has been carried out nowadays in the felsic rocks from the IP upper units.

\subsection{Units of the Órdenes Complex}

The basal units consist of metasediments alternating with granitic orthogneisses and metabasites. The sediments include phyllites, schists, metagraywakes and paragneisses. The metagranitoids have meta- to peraluminous character, and calc-alkaline, alkaline and peralkaline compositions (Abati et al., 2010; Díez Fernández et al., 2011). The metabasites have tholeiitic composition and some of them may correspond to alkali basalts. The calc-alkaline orthogneisses are related to a magmatic arc generated during subduction and they yield U$\mathrm{Pb}$ ages between 490 and $475 \mathrm{Ma}$ (Abati et al., 2010; Díez Fernández et al., 2011; Santos Zalduegui et al., 1995). The bimodal, partially alkaline magmatism reflects

tween 480 and 475 Ma (Díez Fernández et al., 2011; Montero et al., 2009; Rodríguez et al., 2007), which probably resulted in the breaking and drifting away of a peri-Gondwanan terrane, and the opening of the Rheic Ocean (Díez Fernández et al., 2011; Martínez Catalán et al., 2009). The basal units are interpreted as fragments of the most external edge of the Gondwanan continental margin because they are not separated from the lower allochthon by ophiolites.

The ophiolitic units crop out discontinuously underlying the upper units and they are composed of at least two different

lites (Arenas et al., 2007b). Those occupying the higher structural position represent the basal section of an ophiolite sequence, and their geochemistry indicates a supra-subduction character (Sánchez Martínez et al., 2007b). Zircon grains extracted from leucogabbros of this unit yield a concordant U-Pb age of $395 \mathrm{Ma}$ (Diaz García et al., 1999a; Pin et al., 2002). The structurally lower ophiolitic units consist of greenschist facies, volcanic and plutonic mafic rocks (greenstones) and metapelites, with rare felsic orthogneisses, serpentinites, and cherts, all strongly sheared. These ophiolites are interpreted as remnants of an oceanic crust which has been related to the early opening of the Rheic Ocean, during Cambrian times (Arenas et al., 2007c).

The upper units occupy the core of the Órdenes Complex and they are composed of terrigenous metasediments, orthogneisses and metabasites (metagabbros, eclogites, mafic granulites and amphibolites), with ultramafic rocks in the HP-HT upper units. The gabbros and orthogneisses yield $\mathrm{U}-\mathrm{Pb}$ ages around $500 \mathrm{Ma}$, whereas detrital zircons in the metasediments indicate a maximum depositional age of 530-500 Ma for the uppermost greenschist facies metagraywackes (Fernández Suárez et al., 2003; Fuenlabrada et al., 2010). The geochemical signature of the igneous rocks in the HP-HT upper units has been compared to MORB and related to continental rifting (Gil Ibarguchi et al., 1990), whereas mafic rocks in the intermediate P upper units have arc tholeiitic affinities (Andonaegui et al., 2002; Castiñeiras, 2005).

The Corredoiras unit is one of the intermediate pressure upper units of the Órdenes Complex (Fig. 2). It crops out to the southwest of the Complex, occupying a lower structural position (González Cuadra, 2007). This unit displays a heterogeneous deformation and distribution of metamorphism. Two burial and exhumation episodes can be deduced based on its structure, relative chronology and metamorphism, the first occurs in granulite facies conditions and the second in amphibolite facies conditions (González Cuadra, 2007). Available ages point out to an igneous protolith emplacement for this unit at $500 \mathrm{Ma}$, a first burial episode between 493 and $484 \mathrm{Ma}$, and a second episode with exhumation finished at $375 \mathrm{Ma}$ (Abati et al., 1999; Dallmeyer et al., 1997). The Corredoiras Unit consists of 
metasediments and the metaigneous rocks of the Corredoiras massif. Metasediments are pelites (granulitic gneisses and schists) and greywackes (paragneisses and migmatites). Metaigneous rocks derive from acid and intermediate intrusive bodies (granodioritic, tonalitic and amphibole-rich orthogneisses) and basic bodies (metagabbros and amphibolites). They show a heterogeneous deformation, ranging from virtually undeformed and preserving their igneous texture to rocks with a strong mylonitic fabric. We have selected the less deformed samples for the geochemistry study, although some protomylonitic rocks have also been analyzed.

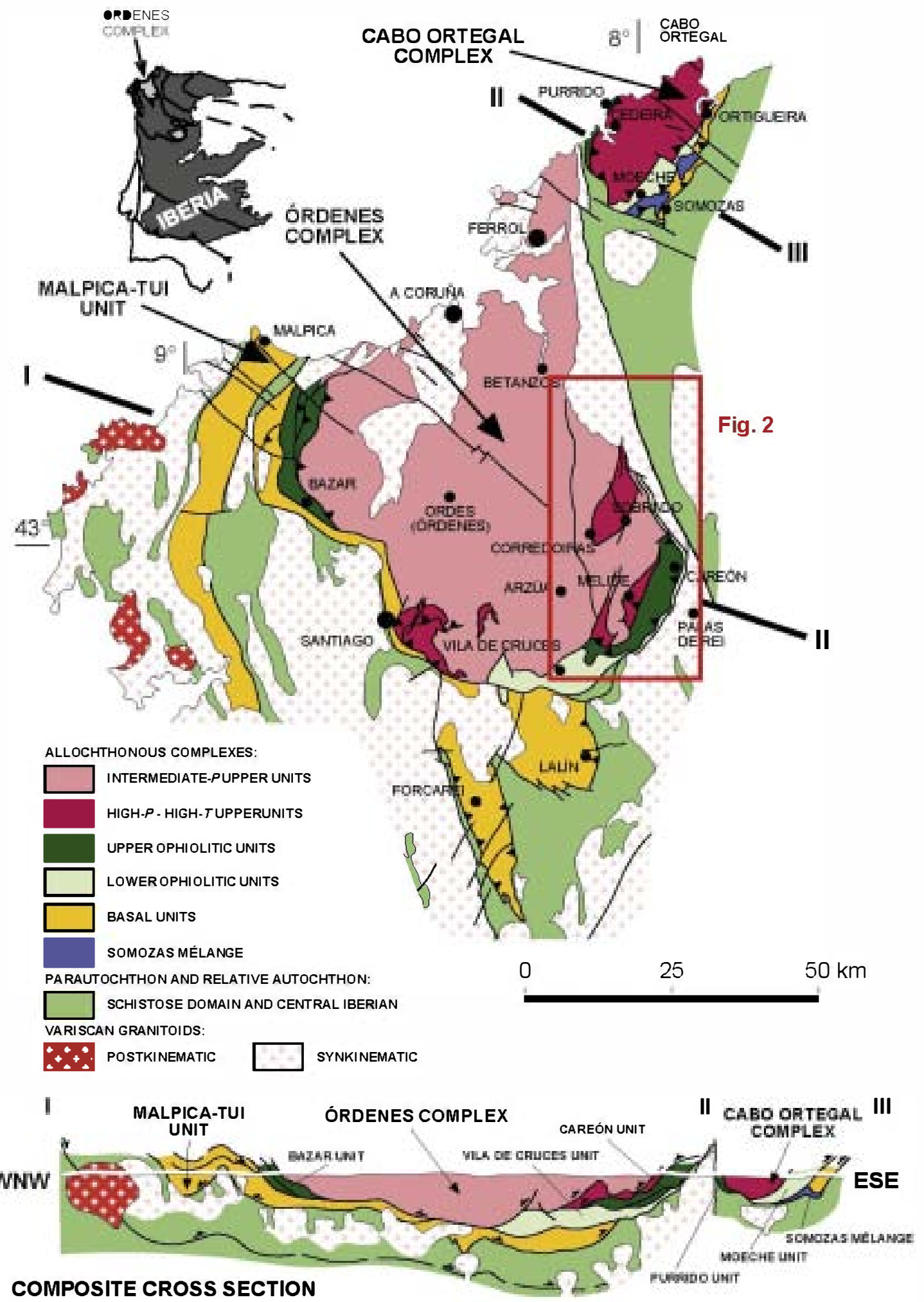

Fig. 1. Terrane distribution in the allochthonous complexes of NW Iberia (Galicia) and a WNW-ESE oriented general cross section. The map shows the synformal structure of the complexes where a rootless branch of the main suture of Pangea in Europe is exposed. The location of the geological map presented in Fig. 2 is also shown. 


\section{Description of the Corredoiras orthogneisses and related rocks}

The Corredoiras metaigneous massif is mainly composed of a large body of orthogneisses. In detail, the following lithologies can be distinguished in the Corredoiras massif (Fig. 2): granodioritic orthogneiss, which constitutes the major part of the unit and it has been mapped in different color tones according to their deformation degree; tonalitic orthogneiss, which crops out at a small area to the NW of the massif; amphibole-rich orthogneiss, which is very scarce and appears associated to the previous lithology; and small bodies of metagabbros scattered within the orthogneisses. The orthogneisses include centimeter to meter-scale metapelitic xenoliths of ellipsoidal shape when they are not deformed. When deformed, they are thinner and develop boudinage textures. The undeformed xenoliths show granulite facies metamorphic conditions, with quartz, biotite and garnet. The deformed xenoliths are transformed into staurolite schists.

The most abundant lithology in the Corredoiras massif is a hypidiomorphic granular coarse-grained granodiorite. Principal minerals are potassium feldspar and plagioclase phenocrysts, quartz and biotite; minor minerals include garnet, apatite, ilmenite, rutile, zircon, titanite, monazite and tourmaline, the latter only present in undeformed or slightly deformed rocks. Muscovite, chlorite and epidote appear as secondary minerals. Most of the Corredoiras orthogneisses have a weak foliation or are isotropic, except in shear zones where

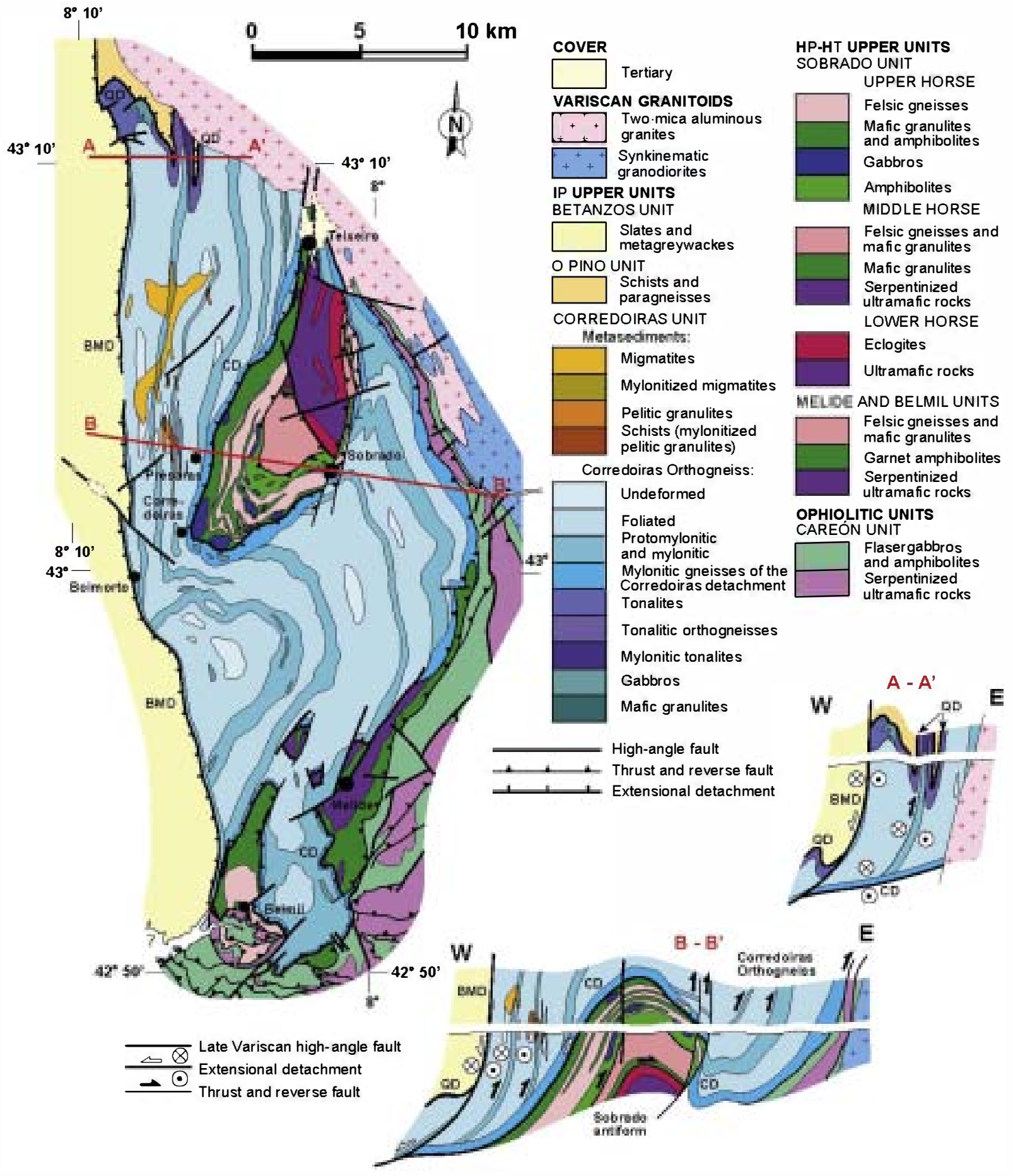

Fig. 2. Geological map of the Corredoiras massif and other important units in the eastern part of the Órdenes Complex (González Cuadra, 2007). 
the texture is gneissic grading to mylonitic or cataclastic. Plagioclase is present in two different

subhedral lath lamellae twin phenocrysts with weak oscillatory zonation, or as small myrmekite crystals surrounding potassium feldspar. Perthite microtextures are common in potassium feldspar phenocrysts, which also exhibit simple twinning and include small plagioclase crystals. Garnet is anhedral and free of inclusions. Deformation in these rocks is accompanied by grain size reduction and mineral stretching (González Cuadra, 2007). Quartz is deformed and recrystallized forming irregular aggregates with biotite, making the rock look darker and apparently richer in biotite. Potassium feldspar, plagioclase and garnet preserve its initial aspect, and develop a microscopically incipient foliation. When the deformation increases these minerals are finally broken and recrystallized, in parallel bands with grain size reduction and developing a gneissic compositional layering.

Tonalitic orthogneisses are medium grained, granular and hypidiomorfic. They are composed of quartz, plagioclase, potassium feldspar, biotite, garnet and, in some samples, hornblende. Subordinate minerals are apatite, zircon, ilmenite, titanite and monazite. These orthogneisses have mainly tonalitic to granodioritic composition, but rare monzogranitic types can also be found. Their texture consists of a plagioclase and potassium feldspar network with intergranular quartz. Their petrographic features are similar to those of the granodioritic orthogneisses. When amphibole is present, it forms intergrowth aggregates with biotite. Garnet may exhibit opaque and quartz inclusions. Deformed types develop a biotite lepidoblastic texture with elongated quartz-feldspar aggregates and an intense grain size reduction.

Macroscopic and microscopic enclaves have been found in both types of orthogneisses, formed by biotite, quartz, plagioclase and muscovite. The micas of the enclaves are quite different

rock ones, biotite is greenish and has fewer accessory minerals included, and muscovite is more birefringent. Less common minerals are hornblende, garnet, tourmaline, titanite and epidote.

Amphibole-rich orthogneisses appear as boudins within the tonalitic orthogneisses, ranging in size from decimeters to meters. They are composed of hornblende, garnet, plagioclase, potassium feldspar and quartz. Accessory minerals are ilmenite, zircon and titanite. Chlorite, epidote and zoisite appear as secondary minerals. They exhibit nematoblastic texture with medium grain size and a strong orientation of hornblende and plagioclase-quartz aggregates defining a compositional layering. Plagioclase, quartz and potassium feldspar appear as more or less equigranular aggregates. Potassium feldspar has thin perthites, whereas plagioclase can appear either as medium sized crystals with lamellar twinning or as small crystals with myrmekite texture around potassium feldspar. Garnet forms small aggregates, usually inclusion-free, but in some samples there is a core with microfolded opaque inclusions and a rim without inclusions.

The metagabbros are found as dispersed bodies within the orthogneisses. The field relationships between both rocks are not clear; nevertheless, some gabbroic bodies contain small amounts of quartz and potassium feldspar, suggesting some mechanical contamination with the granodiorites. For that reason, we interpret that the metagabbros probably intruded the orthogneisses when they were still unconsolidated, generating contaminated lithologies. An additional evidence for mechanical contamination is a tonalitic orthogneiss outcrop, where an area with abundant metagabbro enclaves shows a possible magma mingling process between both lithologies. All these observations suggest that all the different

the Corredoiras Unit are coeval, and they intruded at virtually the same time. Some metagabbros preserve a granular or intergranular to subophitic igneous texture, with medium to coarse grain size, moreover this igneous texture can be recognized because plagioclase crystals are hypidiomorfic with polysynthetic twinning and weak optic zoning, and pyroxene crystals are large (up to $8 \mathrm{~mm}$ ) and exhibit a subophitic texture. They are composed of plagioclase, orthopyroxene, clinopyroxene and sporadic olivine, whereas subordinate minerals are biotite, ilmenite, and apatite, allowing a more precise classification as metagabbronorites. Amphibole and garnet can develop depending on the metamorphic conditions. Secondary minerals are chlorite, epidote and actinolite-tremolite. The pyroxenes are always intergranular with exsolution lamellae, and olivine shows pyroxene-amphibole symplectitic rims.

Quartz appears as small interstitial crystals and as bigger xenocrysts in the contaminated metagabbronorites.

\section{Geochemistry}

\subsection{Analytical methods}

Forty-nine samples ( $>5 \mathrm{~kg}$ each) of the different lithologies Corredoiras massif selected from the best-preserved outcrops were analyzed for whole rock geochemistry (major, minor and trace elements). Among them there are twenty-nine granodioritic orthogneiss samples, nine tonalitic orthogneisses, two amphibole-rich orthogneisses and nine metagabbronorites. Taking into account their deformation features, the granodioritic orthogneisses can be divided into undeformed (13 samples), weakly foliated (9 samples) and foliated/ protomylonitic (7 samples).

The samples were crushed with a steel jaw crusher and powdered to 200 mesh grain size in an agate mill at the laboratories of the Universidad Complutense de Madrid, and the subsequent chemical analyses were carried out at the Activation Iaboratories Ltd. (Actlabs) in Canada using the procedure 4Lithoresearch. The digestion procedure was lithium metaborate/tetraborate fusion, and the analytical technique used to measure elemental concentrations was inductively coupled plasma mass spectrometry (ICP-MS).

$\mathrm{U}-\mathrm{Th}-\mathrm{Pb}$ analyses of zircon were conducted at the Bay SHRIMPRG (co-owned between the U.S. Geological Survey and the Stanford University) during one analytical session in October 2005. Zircon separation was carried out at the Universidad Complutense (Madrid) following standard techniques, including crushing, pulverizing, sieving, Wilfley

were handpicked under a binocular microscope and representative grains were chosen in accordance with their size, length-to-breadth ratio, roundness, color, and other salient morphological features. They were mounted on a double-sided adhesive on glass slides in $1 \times 6 \mathrm{~mm}$ parallel rows together with some chips of zircon standard R33 (Black et al, 2004). After being set in epoxy resin, the zircon grains were ground down to expose their central portions. Internal structure, inclusions, fractures and physical defects were identified with transmitted and reflected

and with cathodoluminescence on a JEOL 5800LV electron microscope (housed at USGS-Denver).

Secondary ions generated from the target spot with an $\mathrm{O}^{2-}$ primary ion beam varying from 4 to $6 \mathrm{nA}$. The primary ion beam produced a spot with a diameter of $\sim 30 \mu \mathrm{m}$ and a depth of 1-2 $\mu \mathrm{m}$ for an analysis time of $8-10 \mathrm{~min}$. Five scans were collected, and the counting time for ${ }^{206} \mathrm{~Pb}$ was increased according to the Paleozoic age of the sample to improve counting statistics and precision of the ${ }^{206} \mathrm{~Pb} /{ }^{238} \mathrm{U}$ age. Concentration data for zircon are standardized against zircon standard CZ3 (550 ppm U, Pidgeon et al., 1995), and isotope ratios were calibrated against $\mathrm{R} 33\left({ }^{206^{*}} \mathrm{~Pb} /{ }^{238} \mathrm{U}=0.06716\right.$, equivalent to an age of $419 \mathrm{Ma}$, Black et al., 2004) which were analyzed repeatedly throughout the duration of the analytical session.

Data reduction follows the methods described by Ireland and Williams (2003) and Williams (1998), and SQUID (version 1.08) and ISOPLOT (version 3.00) software (Ludwig, 2002, 2003) were used. The $\mathrm{Pb}$ composition used for initial $\mathrm{Pb}$ corrections was ${ }^{204} \mathrm{~Pb}$ / ${ }^{206} \mathrm{~Pb}=0.0554,{ }^{207} \mathrm{~Pb} /{ }^{206} \mathrm{~Pb}=0.864$ and ${ }^{208} \mathrm{~Pb} /{ }^{206} \mathrm{~Pb}=2.097$, calculated by SQUID using the Stacey and Kramers (1975) model. 
Twelve samples were selected for $\mathrm{Sm}-\mathrm{Nd}$ and $\mathrm{Rb}-\mathrm{Sr}$ geochemistry, five granodioritic orthogneisses, four tonalitic orthogneisses and three metagabbronorites. The analyses were carried out at the U.S. Geological Survey (Denver), following the analytical procedures described in Premo and Loucks (2000). Whole rock powders were dissolved in $7 \mathrm{ml}$ PFA teflon

$+\mathrm{HNO}_{3}$, and then spiked with a dilute mixed tracer of ${ }^{84} \mathrm{Sr}-{ }^{87} \mathrm{Rb}$ and ${ }^{150} \mathrm{Nd}-{ }^{149} \mathrm{Sm}$. The effluent

(30 ml resin-volume) column with AG50W-X8 cation exchange resin, separating $\mathrm{Rb}, \mathrm{Sr}$, and REE. Sm was separated from Nd using AG50W-X8 cation exchange resin and alpha-hydroxyisobutyric acid method of Lugmair et al. (1975), and then they were both loaded with dilute $\mathrm{H}_{3} \mathrm{PO}_{4}$ acid onto tantalum filaments in triple filament mode and run on a multi-sample VG lsomass 54R mass spectrometer.
4.2. Major and trace element geochemistry

\subsubsection{Major element composition}

Average values of the results for major oxides and trace element analyse of the Corredoiras massif are listed in Table 1, (the complete dataset is provided in the Supplemental data Table A1). Granodioritic orthogneisses are felsic rocks, with $\mathrm{SiO}_{2}$ wt.\% varying from 66.6 to 75.1 (average 69.8). The compositional ranges for the rest of the major elements vary between 15.7 and 13.9 for $\mathrm{Al}_{2} \mathrm{O}_{3}, 6.2-1.5$ for $\mathrm{Fe}_{2} \mathrm{O}_{3} \mathrm{~T}, 1.4-0.3$ for $\mathrm{MgO}, 3.5-1.2$ for $\mathrm{CaO}, 3.5-2.5$ for $\mathrm{Na}_{2} \mathrm{O}$ and 4.92.2 for $\mathrm{K}_{2} \mathrm{O}$. Tonalitic orthogneisses range from intermediate to felsic compositions (58.1-73.7 $\mathrm{SiO}_{2} \mathrm{wt} . \%$ ) with an average composition of 64.9 and they have higher contents in $\mathrm{Al}_{2} \mathrm{O}_{3}, \mathrm{Fe}_{2} \mathrm{O}_{3} \mathrm{~T}, \mathrm{MgO}, \mathrm{CaO}$ and $\mathrm{Na}_{2} \mathrm{O}$ than the granodioritic orthogneisses (16.1-13.4, 9.6-2.4, 2.4-

Table 1

Major and trace element average composition of Corredoiras metaigneous rocks.

\begin{tabular}{|c|c|c|c|c|c|c|c|}
\hline \multirow[t]{2}{*}{ Sample } & \multicolumn{3}{|c|}{ Granodioritic orthogneisses } & \multirow{2}{*}{$\frac{\text { Tonalitic orthg. }}{(\mathrm{n}=9)}$} & \multicolumn{2}{|l|}{ Metagabbros } & \multirow{2}{*}{$\frac{\text { Amphibole orthg }}{(n=2)}$} \\
\hline & $\begin{array}{l}\text { Undeformed } \\
(n=13)\end{array}$ & $\begin{array}{l}\text { Foliated } \\
(n=9)\end{array}$ & $\begin{array}{l}\text { Protomylonitic } \\
(\mathrm{n}=7)\end{array}$ & & $\begin{array}{l}\text { Uncontaminated } \\
(n=6)\end{array}$ & $\begin{array}{l}\text { Contaminated } \\
(n=3)\end{array}$ & \\
\hline $\mathrm{SiO}_{2}$ & 70.53 & 69.13 & 69.69 & 64.86 & 47.83 & 51.69 & 71.54 \\
\hline $\mathrm{TiO}_{2}$ & 0.50 & 0.55 & 0.63 & 0.83 & 0.84 & 1.32 & 0.69 \\
\hline $\mathrm{Al}_{2} \mathrm{O}_{3}$ & 14.55 & 14.90 & 14.00 & 14.94 & 17.65 & 15.62 & 12.37 \\
\hline $\mathrm{Fe}_{2} \mathrm{O}_{3} \mathrm{~T}$ & 3.30 & 3.71 & 4.13 & 6.61 & 8.80 & 9.87 & 4.53 \\
\hline $\mathrm{MnO}$ & 0.05 & 0.06 & 0.07 & 0.11 & 0.13 & 0.15 & 0.06 \\
\hline $\mathrm{MgO}$ & 0.78 & 0.89 & 0.85 & 1.30 & 10.29 & 7.21 & 0.80 \\
\hline $\mathrm{CaO}$ & 2.25 & 2.28 & 2.36 & 2.54 & 9.10 & 8.63 & 5.15 \\
\hline $\mathrm{Na}_{2} \mathrm{O}$ & 3.13 & 3.17 & 3.04 & 3.70 & 2.36 & 2.79 & 3.03 \\
\hline $\mathrm{K}_{2} \mathrm{O}$ & 3.32 & 3.29 & 3.58 & 3.12 & 0.24 & 0.73 & 0.19 \\
\hline $\mathrm{P}_{2} \mathrm{O}_{5}$ & 0.22 & 0.21 & 0.23 & 0.30 & 0.10 & 0.15 & 0.20 \\
\hline LOI & 0.88 & 1.11 & 0.82 & 0.82 & 2.23 & 1.72 & 1.07 \\
\hline Total & 99.51 & 99.30 & 99.40 & 99.13 & 99.58 & 99.88 & 99.63 \\
\hline$\# \mathrm{Mg}$ & 0.18 & 0.16 & 0.15 & 0.16 & 0.48 & 0.37 & 0.15 \\
\hline ACKN & 1.13 & 1.15 & 1.06 & 1.06 & 0.85 & 0.74 & 0.85 \\
\hline $\mathrm{Ba}$ & 1204 & 1250 & 1297 & 593 & 100.83 & 317 & 45.50 \\
\hline $\mathrm{Rb}$ & 84 & 85 & 93 & 103 & 6 & 14 & 4 \\
\hline $\mathrm{Sr}$ & 183 & 187 & 161 & 153 & 208 & 174 & 509 \\
\hline Тa & 0.66 & 0.77 & 0.82 & 1.08 & 0.19 & 0.38 & 0.77 \\
\hline $\mathrm{Nb}$ & 9.80 & 10.90 & 12.50 & 14.60 & 3.30 & 6.50 & 10.20 \\
\hline $\mathrm{Hf}$ & 5.89 & 6.84 & 9.16 & 9.38 & 1.98 & 4.33 & 6.25 \\
\hline $\mathrm{Zr}$ & 224 & 270 & 301 & 355 & 78 & 167 & 249 \\
\hline $\mathrm{Y}$ & 49 & 55 & 69 & 46 & 16 & 33 & 29 \\
\hline Th & 15.13 & 16.39 & 21.46 & 9.86 & 0.94 & 6.08 & 6.27 \\
\hline $\mathrm{U}$ & 1.88 & 2.20 & 2.13 & 2.72 & 0.11 & 0.43 & 1.72 \\
\hline $\mathrm{Cr}$ & 55 & 54 & 64 & 69 & 418 & 350 & 75 \\
\hline $\mathrm{Ni}$ & 19 & 19 & 19 & 20 & 157 & 83 & 19 \\
\hline V & 38 & 44 & 45 & 73 & 129 & 204 & 73 \\
\hline $\mathrm{Pb}$ & 34 & 33 & 38 & 26 & 4 & 11 & 4 \\
\hline $2 n$ & 47 & 53 & 50 & 101 & 72 & 90 & 40 \\
\hline $\mathrm{Th} / \mathrm{Ta}$ & 22.92 & 21.29 & 26.17 & 9.13 & 5.59 & 16.03 & 8.14 \\
\hline $\mathrm{Th} / \mathrm{Yb}$ & 3.38 & 3.33 & 3.09 & 2.09 & 0.57 & 1.82 & 2.46 \\
\hline La & 41.31 & 46.71 & 57.77 & 29.20 & 7.17 & 20.57 & 25.42 \\
\hline $\mathrm{Ce}$ & 86.54 & 94.49 & 124.01 & 75.68 & 15.32 & 44.20 & 52.35 \\
\hline $\operatorname{Pr}$ & 10.55 & 11.95 & 14.49 & 8.20 & 2.09 & 5.54 & 6.84 \\
\hline Nd & 41.19 & 46.71 & 55.44 & 33.11 & 9.28 & 23.33 & 26.70 \\
\hline Sm & 9.47 & 10.26 & 12.49 & 7.80 & 2.49 & 5.70 & 6.15 \\
\hline $\mathrm{Eu}$ & 1.50 & 1.56 & 1.70 & 1.73 & 1.03 & 1.40 & 1.33 \\
\hline $\mathrm{Gd}$ & 9.36 & 1.026 & 12.22 & 8.05 & 2.94 & 6.24 & 5.99 \\
\hline $\mathrm{Tb}$ & 1.59 & 1.75 & 2.08 & 1.37 & 0.48 & 1.03 & 1.04 \\
\hline Dy & 8.81 & 9.79 & 11.96 & 7.67 & 2.82 & 5.93 & 5.40 \\
\hline Ho & 1.70 & 1.92 & 2.46 & 1.54 & 0.57 & 1.18 & 1.03 \\
\hline $\mathrm{Er}$ & 4.99 & 5.60 & 7.38 & 4.67 & 1.70 & 3.48 & 2.81 \\
\hline $\mathrm{Tm}$ & 0.74 & 0.82 & 1.12 & 0.74 & 0.25 & 0.53 & 0.41 \\
\hline $\mathrm{Yb}$ & 4.47 & 4.92 & 6.94 & 4.71 & 1.64 & 3.33 & 2.54 \\
\hline $\mathrm{Lu}$ & 0.63 & 0.69 & 0.99 & 0.69 & 0.24 & 0.49 & 0.36 \\
\hline$\sum \mathrm{REE}$ & 222.50 & 246.56 & 310.70 & 183.73 & 48.02 & 122.97 & 137.33 \\
\hline$(\mathrm{La} / \mathrm{Yb})_{\mathrm{N}}$ & 6.18 & 6.35 & 5.57 & 4.15 & 2.98 & 4.11 & 6.69 \\
\hline
\end{tabular}

$\# \mathrm{Mg}=\left(\mathrm{Mg}^{+2} /\left[\mathrm{Mg}^{+2}+\mathrm{Fe}^{+2} \mathrm{~T}\right]\right)$. 
$0.4,4.4-0.9,4.0-3.4$, respectively) and similar content in $\mathrm{K}_{2} \mathrm{O}$ (4.11.9). $\mathrm{Na}_{2} \mathrm{O}$ concentration is relatively high ( $\left.\geq 3 \mathrm{wt} . \%\right)$, which is characteristic of I-type granites (Hine et al., 1978), even though the $\mathrm{K}_{2} \mathrm{O}$ / $\mathrm{Na}_{2} \mathrm{O}$ ratios are near 1 , typical of calc-alkaline rocks.

The two amphibole-rich orthogneisses samples are felsic in composition (66.8-76.3), with similar $\mathrm{MgO}$ and $\mathrm{CaO}$ contents (0.9-0.7 and $0.18-0.19$, respectively) and different

of the major elements, so sample 107939 has higher $\mathrm{Al}_{2} \mathrm{O}_{3}, \mathrm{Fe}_{2} \mathrm{O}_{3} \mathrm{~T}$ and $\mathrm{Na}_{2} \mathrm{O}$ contents and lower $\mathrm{CaO}$ than sample 107940.

The $\mathrm{SiO}_{2}$ wt.\% from metagabbronorites varies from 45.6 to 52.5 , as corresponds to basic rocks. As mentioned above, some metagabbronorites seem contaminated by interaction with the felsic magmas, which is also supported by the chemistry: compared to the uncontaminated metagabbronorites, the contaminated ones are enriched in $\mathrm{SiO}_{2}$ (average 51.7 wt.\% compared to $47.8 \mathrm{wt} . \%$ ), $\mathrm{Na}_{2} \mathrm{O}$ (2.8 compared to 2.4 ) and $\mathrm{K}_{2} \mathrm{O}$ (0.7 compared to 0.2), whereas they are depleted in $\mathrm{Fe}_{2} \mathrm{O}_{3} \mathrm{~T}$ (9.5 against 9.8), $\mathrm{MgO}$ (7.2 against 10.3), $\mathrm{CaO}$ (8.5 against 9.1) and $\mathrm{Al}_{2} \mathrm{O}_{3}$ (15.6 against 17.7$)$.

All of the Corredoiras rocks show systematic trends of decreasing $\mathrm{Al}_{2} \mathrm{O}_{3}, \mathrm{Fe}_{2} \mathrm{O}_{3} \mathrm{~T}, \mathrm{MgO}, \mathrm{TiO}_{2}$ and $\mathrm{P}_{2} \mathrm{O}_{5}$ with increasing $\mathrm{SiO}_{2}$. $\mathrm{MgO}$ content in orthogneisses is low, with \#Mg (\#Mg $=\left(\mathrm{Mg}^{+2} /\left[\mathrm{Mg}^{+2}+\mathrm{Fe}^{+2} \mathrm{~T}\right]\right)$ ) ranging from 0.17 to 0.09 , decreasing with increasing $\mathrm{SiO}_{2}$. The metagabbronorites show higher \#Mg from 0.53 to 0.38 , but these are relatively low for basic rocks, meaning that they do not represent primary magmas. These basic rocks are probably equivalent to the Monte Castelo gabbros, a huge gabbroic massif outcropping in the western part of the intermediate pressure upper units (Andonaegui et al., 2002).

In an AFM diagram, (Fig. 3a, Irvine and Baragar, 1971) the orthogneisses define a calc-alkaline suite, whereas the metagabbronorites plot in the tholeiitic field close to the line dividing both fields. In order to precisely determine the magmatic series of the metagabbronorites, we have used the Th vs. Co diagram (Fig. 3b, Hastie et al.,
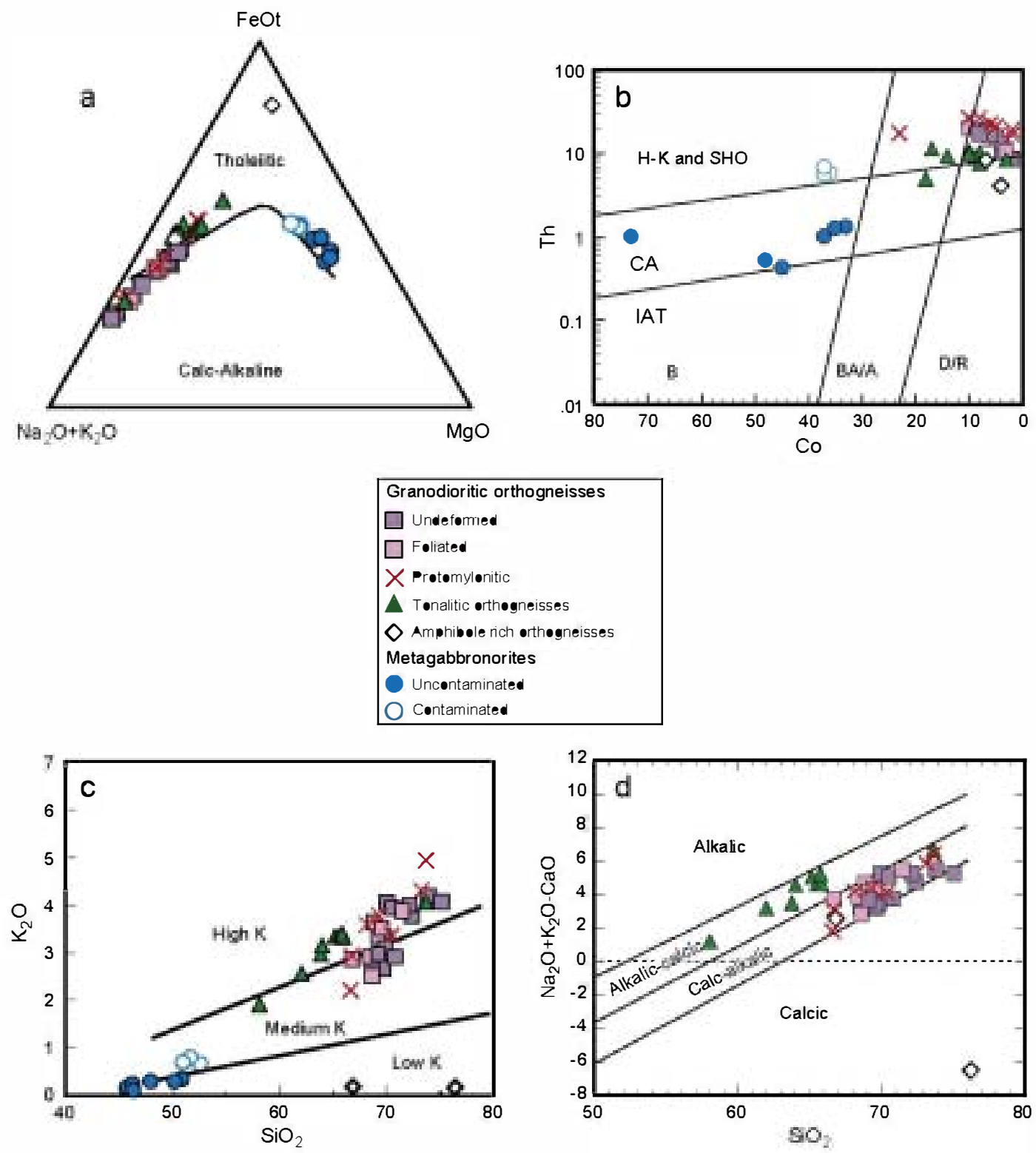

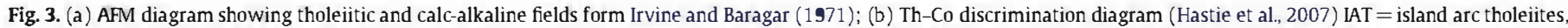

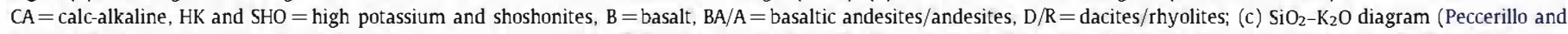

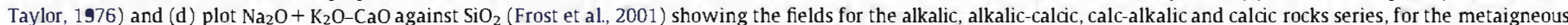
rocks of the Corredoiras massif. 
2007), where island arc tholeiites can be discriminated from the calcalkaline series. The uncontaminated metagabbronorites plot in the field of the calc-alkaline basalts, whereas the contaminated ones are detached from them, plotting in the field of high-potassium basalts. The orthogneisses also plot in the field of high-potassium rocks.

In the Peccerillo and Taylor (1976) diagram (Fig. 3c), the orthogneisses define a high-potassium calc-alkaline suite, whereas the metagabbros plot in the low-potassium field, except for the contaminated gabbros that plot in the medium-potassium field. Amphibolerich orthogneisses are depleted in potassium and plot in the lowpotassium field accordingly.

In the $\mathrm{Na}_{2} \mathrm{O}+\mathrm{K}_{2} \mathrm{O}-\mathrm{CaO}$ vs. $\mathrm{SiO}_{2}$ diagram (Fig. 3d, Frost et al., 2001) the granodioritic orthogneisses plot in the field of the calc-alkalic series, whereas the tonalitic orthogneisses plot in the field of the alkalic-calcic series, owning to their higher $\mathrm{CaO}$ content.

The $\mathrm{A} / \mathrm{CKN}$ ratios (molecular $\mathrm{Al}_{2} \mathrm{O}_{3} /\left[\mathrm{CaO}+\mathrm{Na}_{2} \mathrm{O}+\mathrm{K}_{2} \mathrm{O}\right]$ ) range between 1.09 and 1.38 in the granodioritic orthogneisses and from 1.01 to 1.09 in the tonalitic orthogneisses, indicating a transitional character between low peraluminous to peraluminous. The lower A/CKN values in the tonalitic orthogneisses suggest a more basic precursor. Furthermore, the tonalitic orthogneisses show a marked negative correlation in $\mathrm{P}_{2} \mathrm{O}_{5}$ with increasing silica, a diagnostic feature of I-type granites when apatite reaches saturation in less peraluminous magmas (Chappell, 1999). Both metagabbronorites and amphibolerich orthogneisses are metaluminous.

\subsubsection{Trace element composition}

Average values of race elements are listed in Table 1 . All orthogneisses show enrichment in incompatible elements ( $R b, B a, K, T h, U)$, with some differences

are more enriched in $\mathrm{Ba}(1550-734 \mathrm{ppm})$ and Th (26.9-8.39 ppm) than the tonalitic orthogneisses (Ba 785-326 ppm; Th 4.92-11.2 ppm); they have the opposite behavior regarding $\mathrm{Rb}$, the tonalitic orthogneisses have slightly higher average values $(103 \mathrm{ppm})$ than the granodioritic orthogneisses $(87 \mathrm{ppm})$. The metagabbronorites are less enriched in incompatible elements than the orthogneisses, but again there are differences between contaminated and uncontaminated metagabbronorites; the former are richer in incompatible elements (Ba: $317 \mathrm{ppm}, \mathrm{Rb}$ : $14 \mathrm{ppm}$, Th: $6.1 \mathrm{ppm}$ and U: $0.4 \mathrm{ppm}$, average values) than the latter (100.9 ppm, $6 \mathrm{ppm}, 0.9 \mathrm{ppm}$, and $0.1 \mathrm{ppm}$, respectively). Finally, the amphibole-rich orthogneisses have the lowest contents in incompatible elements.
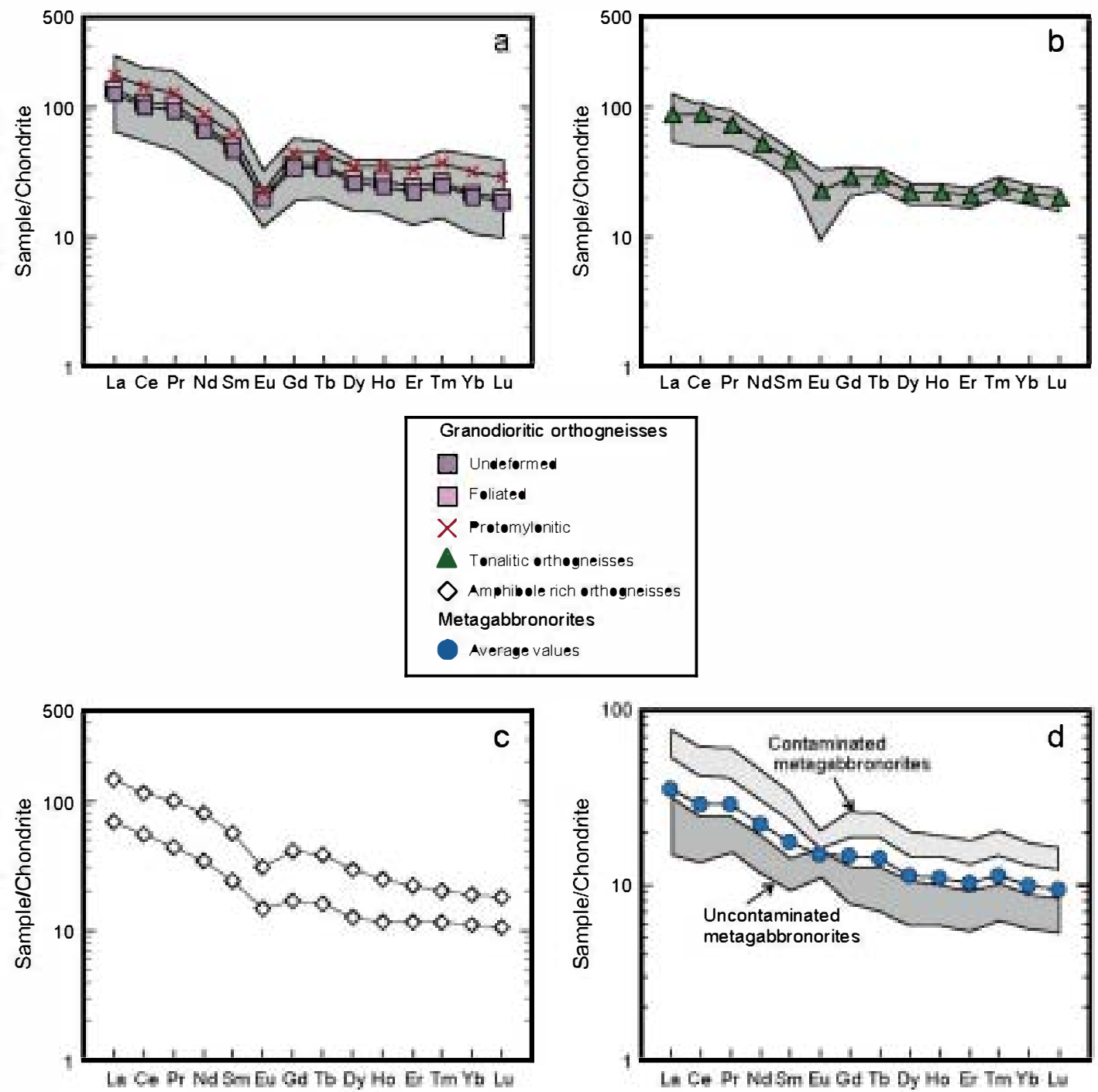

Fig.4. Chondrite-normalized rare earth elements plots for the different metaigneous rocks of the Corredoiras massif, normalizing values are from Nakamura (1974). Shading zone is the rank of total samples variation, and the individual lines correspond to the average of each type rocks. a) Granodioritic orthogneisses; b) tonalitic orthogneisses; c) amphibolerich orthogneisses; d) metagabbronorites. 


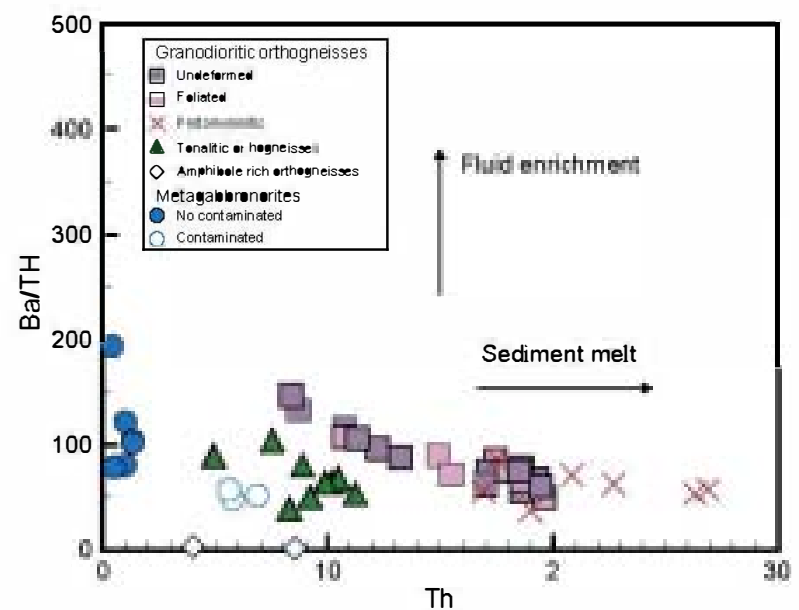

Fig. 5. Ba/Th-Th diagram (Münker et al., 2004) showing that partial melting of sediments had a clear influence on the generation of part of the metaigneous rocks included in the Corredoiras massif.

On primitive mantle normalized diagrams, samples display moderate to strong depletion in $\mathrm{Nb}, \mathrm{Ta}, \mathrm{Sr}, \mathrm{P}$ and Ti, a typical feature of subduction-related magmatic rocks (Brown et al., 1984; Rogers and Hawkesworth, 1989). The tonalitic orthogneisses have higher values in $\mathrm{Nb}$ (average of $14.6 \mathrm{ppm}$ ) and Ta (average of $1.1 \mathrm{ppm}$ ) with respect to the granodioritic orthogneisses (Nb: $11.1 \mathrm{ppm}$, Ta: $0.8 \mathrm{ppm}$, average values). Strontium is slightly higher in the granodioritic orthogneisses (177 ppm average) than in the tonalitic orthogneisses (103 ppm average). The uncontaminated metagabbros have the lowest values in $\mathrm{Nb}$ and $\mathrm{Ta}$ ( 3.3 and $0.2 \mathrm{ppm}$, respectively), and they are slightly enriched in $\mathrm{Sr}(208 \mathrm{ppm})$, while the contaminated metagabbros have somewhat higher $\mathrm{Nb}(6.5 \mathrm{ppm})$ and $\mathrm{Ta}(0.4 \mathrm{ppm})$ and lower contents in Sr (174 ppm). Finally, the amphibole-rich orthogneisses have the highest contents in $\mathrm{Sr}(509 \mathrm{ppm})$, probably because they are richer in plagioclase. These rocks have $\mathrm{Nb}$ and $\mathrm{Ta}$ values similar to those of the other orthogneisses ( $\mathrm{Nb}: 10.2 \mathrm{ppm}$, Ta: $0.8 \mathrm{ppm}$ ).

The orthogneisses also have high Th/Ta ratios (16.2-31.8 for the granodiorites, and 4.4-10.4 for the tonalites), which is typical of subduction-related magmas (Gorton and Schandl, 2000; Rogers and Hawkesworth, 1989).

The granodioritic orthogneisses have total rare earth element (REE) contents ranging between 120 and 425 ppm, and show a negative correlation with the increase in $\mathrm{SiO}_{2}$. The REE concentrations are 10 to 250 times chondritic abundances (Nakamura, 1974), and show fractionated chondrite-normalized patterns $\left[(\mathrm{La} / \mathrm{Yb})_{N}=2.9-10.7\right]$ (Fig. . 4a), typical of calc-alkaline rocks. The light rare earth elements (LREEs) $\left[(\mathrm{La} / \mathrm{Sm})_{\mathrm{N}}=2.5-3.1\right]$ are fractionated compared to the heavy rare earth elements (HREEs) which exhibit a flatter $\left.\mathrm{Yb})_{\mathrm{N}}=0.9-2.7\right]$ with negative Eu anomalies ranging from moderate

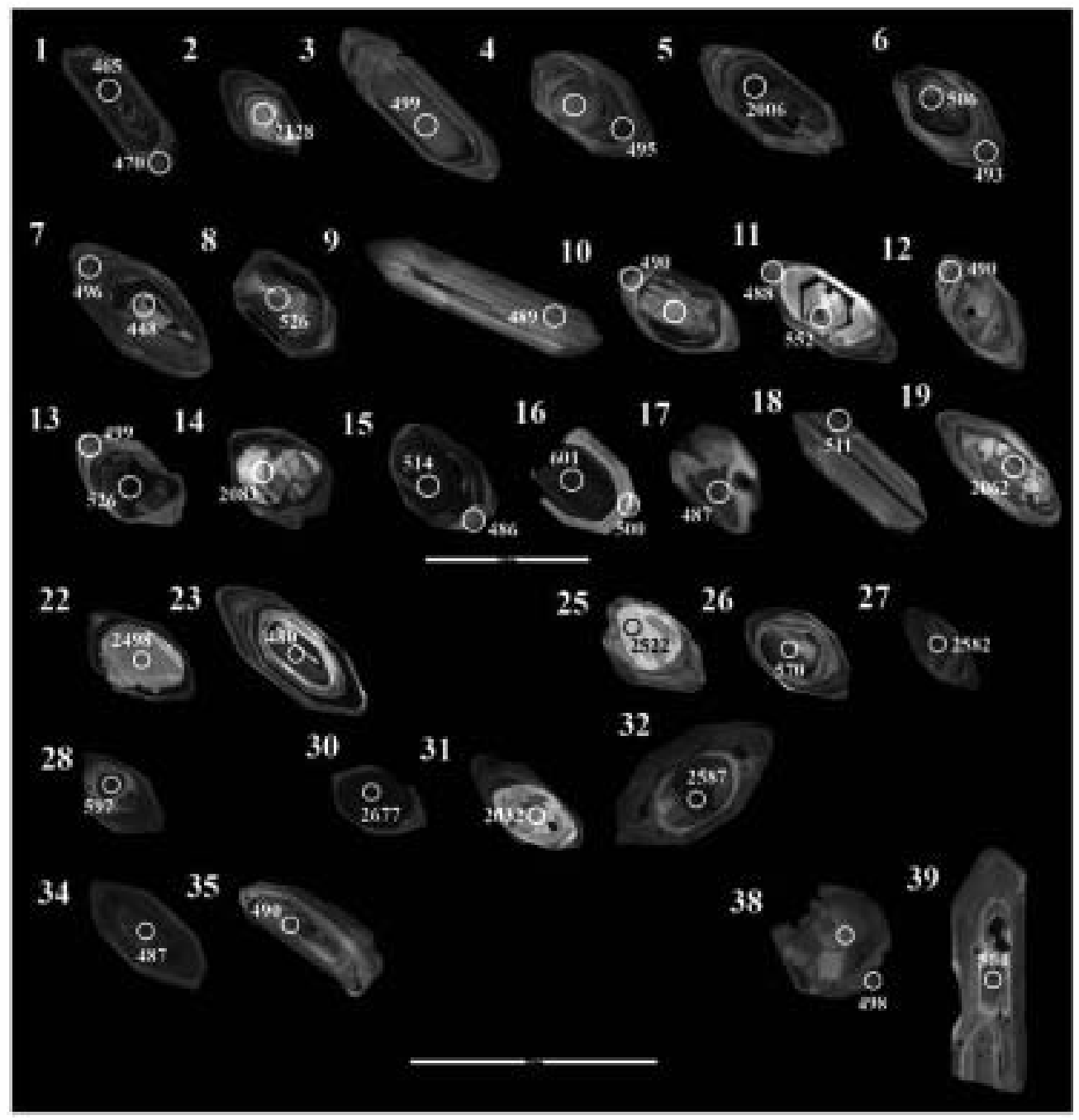

Fig. 6. Cathodoluminescence images for selected zircons from the analyzed sample of orthogneiss. 


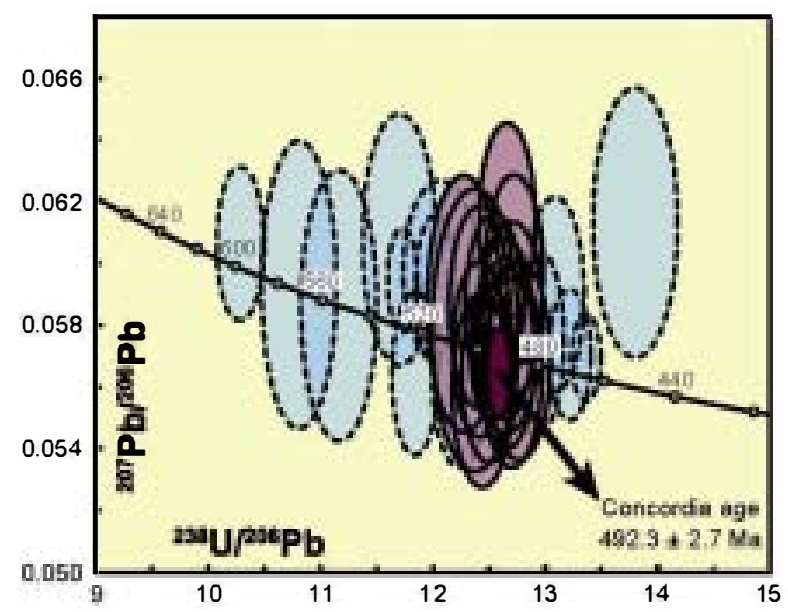

Fig. 7. U-Pb concordia diagram showing the result of zircon analyses.

to pronounced $\left(\left(\mathrm{Eu} / \mathrm{Eu}^{*}\right)=0.3-0.7\right)$. The tonalitic orthogneisses have lower total REE contents (125-225 ppm), with less variation than the granodioritic orthogneisses, and they also show a negative correlation with the increase in silica content. They have concentrations between 15 and 130 times the chondritic abundances. Their chondritenormalized pattern (Fig. . 4b) is parallel to those of the previous samples, although it is less fractionated $\left[(\mathrm{La} / \mathrm{Yb})_{N}=2.5-7.1\right]$ than in the granodioritic orthogneisses. The Eu anomalies are similar in both lithologies $\left(\mathrm{Eu} / \mathrm{Eu}^{*}=0.4-0.9\right)$.

The two amphibole-rich orthogneisses samples have total REE contents lower than the previous orthogneisses (90-190 ppm), with concentrations between 10 and 105 times the chondritic abundances (Fig. . 4c). Their fractionation is similar to the other orthogneisses $\left[(\mathrm{La} / \mathrm{Yb})_{\mathrm{N}}=5.7-7.3\right]$ and they also have negative Eu anomalies (Eu/ $\mathrm{Eu}^{*}=0.6-0.8$ ).

The metagabbronorites have the lowest total contents in REE (150-40 ppm), the highest values corresponding to contaminated metagabbronorites. The concentrations range between 14.9 and $31.6 \mathrm{ppm}$ (20 to 5 times chondritic values) for the uncontaminated metagabbros, and between 52.8 and 77.2 ppm (80 to 12 times chondritic values) for the contaminated metagabbros. The latter show higher fractionation $\left[(\mathrm{Ia} / \mathrm{Yb})_{\mathrm{N}}=3.8-4.1\right]$ than the former $[(\mathrm{La} /$ $\mathrm{Yb})_{\mathrm{N}}=1.7-4.0$ ] (Fig. . 4d). In both cases, the fractionation in HREE is similar $\left[(\mathrm{Gd} / \mathrm{Yb})_{\mathrm{N}}=1.4-1.5\right]$. The contaminated metagabbros have negative $\mathrm{Eu}$ anomalies $\left(\mathrm{Eu} / \mathrm{Eu}^{*}=0.7-0.8\right)$, whereas the uncontaminated metagabbros have positive Eu anomalies $\left(\mathrm{Eu} / \mathrm{Eu}^{*}=1.1-2.3\right)$.

The Corredoiras metaigneous rocks exhibit an enrichment in large ion lithophile elements (LILE) and light rare earth elements (LREE) relative to high field strength elements (HFSE), resulting in a high LILE/HFSE ratio. These geochemical features are the most characteristic of magmas related with subduction zones (Davidson, 1996; Tatsumi and Eggins, 1995). The depletion in HFSE is the consequence of mass flux

tle. Typically there is a preferential mobilization of LIIE in hydrous fluids

concentrated in the continental crust and can be indicative of crustal contamination of magmas.

Nonetheless, there are some geochemical tracers to evaluate if the LILE enrichment is either a consequence of fluid

sult of sediment melting or crustal contamination (Hawkesworth et al., 1997; Münker et al., 2004), for example Ba/Th vs. Th. The rationale behind this diagram is that magmas generated in an intra-oceanic supra-subduction zone derive from the partial melting of the mantle wedge enriched by slab fluids

low concentration in Th and high $\mathrm{Ba} / \mathrm{Th}$ ratio; on the other hand, if the enrichment is due to sediment melting or contamination in continental crust shallow levels, magmas will have high Th concentrations and low $\mathrm{Ba}$ /Th ratio. In this diagram (Fig. 5), the Corredoiras metaigneous rocks show low $\mathrm{Ba} / \mathrm{Th}$ ratio and high Th contents, defining a path that indicates a connection with sediment or continental crust melting. In the case under discussion, we favor continental crust melting. This feature is also evident in the contaminated gabbros as they are richer in $\mathrm{Th}$ and more depleted in $\mathrm{Ba} / \mathrm{Th}$ ratio than the uncontaminated gabbros.

Other ratios in the Corredoiras metaigneous rocks that support the influence

high $\mathrm{Th} / \mathrm{Ce}$ and $\mathrm{Th} / \mathrm{Ta}$ ratios. Specifically, both the granodioritic orthogneisses and the contaminated metagabbronorites show high $\mathrm{Th} / \mathrm{Ta}$ ratios, the latter with an average value of 16.03 . This high value contrasts with the values obtained in the uncontaminated metagabbronorites (average 5.58). High Th/Ta values clearly point out to an influence

continental crust. The tonalitic orthogneisses show $\mathrm{Th} / \mathrm{Ta}$ ratios slightly higher (average 9.13) than the uncontaminated metagabbronorites, indicating an origin from more primitive liquids than the granodioritic orthogneiss with little interaction with continental

Table 2

$\mathrm{Nd}$ and $\mathrm{Sr}$ isotopic data of Corredoiras orthogneisses.

\begin{tabular}{|c|c|c|c|c|c|c|c|c|c|c|c|c|}
\hline Sample & $\begin{array}{l}\text { Age (T) } \\
\text { (Ma) }\end{array}$ & $\begin{array}{l}\text { Sm } \\
(\mathrm{ppm})\end{array}$ & $\begin{array}{l}\text { Nd } \\
\text { (ppm) }\end{array}$ & ${ }^{14} 7 \mathrm{Sm} /{ }^{144} \mathrm{Nd}$ & ${ }^{143} \mathrm{Nd} /{ }^{144} \mathrm{Nd}$ & $\varepsilon_{N d}$ at $T$ & $\begin{array}{l}\mathrm{T}_{\mathbf{M M}} \\
(\mathrm{Ma})\end{array}$ & $\begin{array}{l}\mathrm{Rb} \\
(\mathrm{ppm})\end{array}$ & $\begin{array}{l}\mathrm{Sr} \\
(\mathrm{ppm})\end{array}$ & ${ }^{87} \mathrm{Rb} /{ }^{87} \mathrm{Sr}$ & ${ }^{87} \mathrm{Sr} /{ }^{86} \mathrm{Sr}$ & $\begin{array}{l}{ }^{87} \mathrm{Sr} /{ }^{86} \mathrm{Sr} \\
(\text { at T) }\end{array}$ \\
\hline \multicolumn{13}{|c|}{ Granodiorite orthogneiss } \\
\hline 107890 & 492 & 4.63 & 20.27 & 0.13789 & 0.512294 & -2.98 & 1484 & 96 & 156 & 1.782 & 0.719774 & 0.707075 \\
\hline 107891 & 492 & 5.94 & 25.43 & 0.14103 & 0.512274 & -3.57 & 1578 & 96 & 157 & 1.771 & 0.719517 & 0.706899 \\
\hline $107899^{a}$ & 492 & 8.76 & 41.55 & 0.12728 & 0.512241 & -3.34 & 1403 & 61 & 227 & 0.778 & 0.713232 & 0.707690 \\
\hline 107908 & 492 & 9.26 & 44.31 & 0.12623 & 0.512298 & -2.17 & 1297 & 62 & 230 & 0.780 & 0.713615 & 0.708055 \\
\hline 107928 & 492 & 10.24 & 46.89 & 0.13187 & 0.512277 & -2.93 & 1413 & 83 & 172 & 1.397 & 0.717186 & 0.707230 \\
\hline \multicolumn{13}{|c|}{ Tonalite orthogneiss } \\
\hline 107930 & 492 & 8.11 & 34.11 & 0.14352 & 0.512546 & 1.59 & 1103 & 66 & 149 & 0.849 & 0.710523 & 0.704475 \\
\hline 107931 & 492 & 5.58 & 22.74 & 0.14832 & 0.512597 & 2.28 & 1069 & 149 & 56 & 7.733 & 0.755395 & 0.700296 \\
\hline 107934 & 492 & 6.48 & 29.76 & 0.13139 & 0.512550 & 2.43 & 949 & 108 & 147 & 2.203 & 0.718899 & 0.703205 \\
\hline 107937 & 492 & 7.28 & 31.80 & 0.13818 & 0.512541 & 1.83 & 1042 & 91 & 183 & 1.439 & 0.714712 & 0.704455 \\
\hline \multicolumn{13}{|c|}{ Metagabbros } \\
\hline 107898 & 492 & 2.31 & 8.89 & 0.15670 & 0.512560 & 1.04 & 1291 & 3 & 150 & 0.058 & 0.705182 & 0.704770 \\
\hline 107913 & 492 & 4.11 & 17.13 & 0.14504 & 0.512436 & -0.65 & 1341 & 12 & 162 & 0.214 & 0.706684 & 0.705157 \\
\hline 107925 & 492 & 1.87 & 7.44 & 0.15152 & 0.512575 & 1.83 & 1165 & 9 & 196 & 0.133 & 0.705082 & 0.704136 \\
\hline
\end{tabular}

a Zircon sample. 
crust materials (Hawkesworth et al., 1997). Furthermore, the metagabbronorites show high $\mathrm{Th} / \mathrm{Yb}$ ratios $(>1$ for contaminated and $<1$ for uncontaminated) which are displaced from the MORB-OIB array (Pearce, 2008), suggesting either an upper crustal interaction or an interaction with a mantle lithosphere containing an inherited subduction component.

\section{SHRIMP U-Pb geochronology}

\subsection{Sample description}

One undeformed granodiorite (sample 107899) was selected for geochronological characterization by U-Pb SHRIMP in zircon to confirm the crystallization age of the protolith, previously dated by Abati et al. (1999), and to investigate zircon inheritance. Morphologically, the studied sample contains two zircon populations (Fig. 6), one with high breadth-to-length ratio and rounded edges, and other with acicular shape and idiomorphic habit. Under cathodoluminescence (CL), it is possible to distinguish three different

central areas, there are discontinuous zones which are interpreted as inherited xenocrystic cores. Generally, these cores are mantled by subsequent zircon growth episodes, which developed oscillatory zones, characteristic of igneous zircon. Finally, the oscillatory zones might be cut by a discontinuous non-luminescent rim with homogeneous zoning. Acicular zircon grains can be inherited, but they usually lack xenocrystic cores.

\subsection{Results}

Forty-eight analyses were performed on 38 zircon grains. The whole set of analytical data is in Supplemental data Table A2. Seventeen analyses yielded ages older than $1000 \mathrm{Ma}$ (reported as ${ }^{204} \mathrm{~Pb}$ corrected ${ }^{207} \mathrm{~Pb} /{ }^{206} \mathrm{~Pb}$ ) and after rejecting seven discordant analyses, two distinct populations can be distinguished at $\sim 2.1$ and $\sim 2.5 \mathrm{Ga}$. Ages younger than $1000 \mathrm{Ma}$ (reported as ${ }^{207} \mathrm{~Pb}$-corrected ${ }^{206} \mathrm{~Pb}$ / ${ }^{238} \mathrm{U}$ ) vary between 450 and $600 \mathrm{Ma}$, with an acme at $\sim 490 \mathrm{Ma}$, and their uncorrected radiogenic compositions are plotted in a TeraWasserburg diagram (Fig. 7).

After calculating the median age of the young data and pooling the most concordant ages around the median value, we obtain a concordia age (sensu Ludwig, 1998) of $492.3 \pm 2.7 \mathrm{Ma}$ (Fig. 7). Taking into account this result together with the $\mathrm{CL}$ images, we interpret that this date represents the crystallization age of the granodioritic protolith. Younger ages can be the result of a subsequent metamorphic event or lead loss occurred in the magmatic zircon, whereas slightly older ages can be interpreted as Pan-African inheritance (see Abati et al., 1999, 2007). Other less abundant inherited components include Paleoproterozoic (between 2.0 and $2.1 \mathrm{Ga}$ ) and Neoarchean (around $2.6 \mathrm{Ga}$ ).

\section{Sm-Nd and $\mathrm{Rb}-\mathrm{Sr}$ geochemistry}

The results are in Table 2 . The granodioritic orthogneisses have slightly lower ${ }^{143} \mathrm{Nd} /{ }^{144} \mathrm{Nd}$ values $(0.512241-0.512298)$ than the tonalitic orthogneiss (0.512541-0.512597) or the metagabbros (0.512436$0.512575)$. $\varepsilon N d$ values have been calculated using the crystallization age obtained in sample 107899 by SHRIMP (492 Ma). Initial ${ }^{87} \mathrm{Sr} /{ }^{86}$ Srversus $\varepsilon \mathrm{Nd}_{(492 \mathrm{Ma})}$ values are plotted in Fig. 8, and a clear difference can be established between the felsic and the intermediate to basic Corredoiras rocks. On one hand, the granodioritic orthogneiss samples cluster around negative $\varepsilon \mathrm{Nd}_{(492 \mathrm{Ma})}$ values $(-2.2$ to -3.6$)$ and high $\left({ }^{87} \mathrm{Sr} /{ }^{86} \mathrm{Sr}\right)_{\mathrm{i}}$ ratios $(0.707$ to 0.708$)$. On the other hand, tonalitic orthogneisses and metagabbronorites have positive $\varepsilon \mathrm{Nd}_{(492 \mathrm{Ma})}$ values (1.0 to 2.4 ) and low $\left({ }^{87} \mathrm{Sr} /{ }^{86} \mathrm{Sr}\right)_{\mathrm{i}}$ ratios (0.703 to 0.705$)$. Additionally, two samples from this group are anomalous, a tonalitic orthogneiss (sample 107931) that has

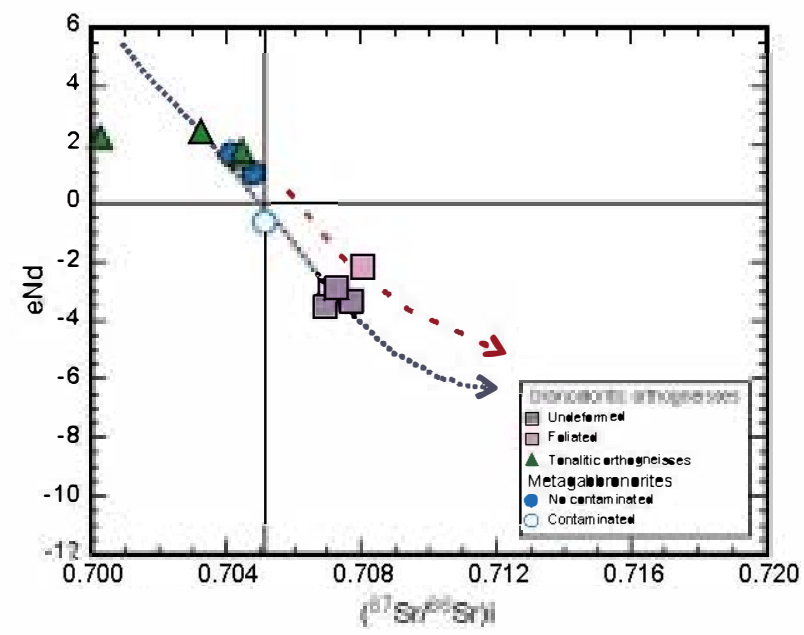

Fig. 8. $\varepsilon_{\text {Na }}$ versus $\left({ }^{8} \mathrm{Sr} /{ }^{26} \mathrm{Sr}\right)$ i diagram for some of the most typical lithologies of the Corredoiras massif. Dotted line: pattern of Andean batholiths (Rogers and Hawkesworth, 1989), broken line: pattern of Lachlan Fold Belt I-type batholiths (McCulloch and Chappell, 1982).

the lowest $\left({ }^{87} \mathrm{Sr} /{ }^{86} \mathrm{Sr}\right)_{\text {i }}$ ratio, which probably reflects isotopic bance during metamorphism, and contaminated metagabbronorite (sample 107913) that has slightly negative $\varepsilon \mathrm{Nd}_{(492 \mathrm{Ma})}$ value and higher
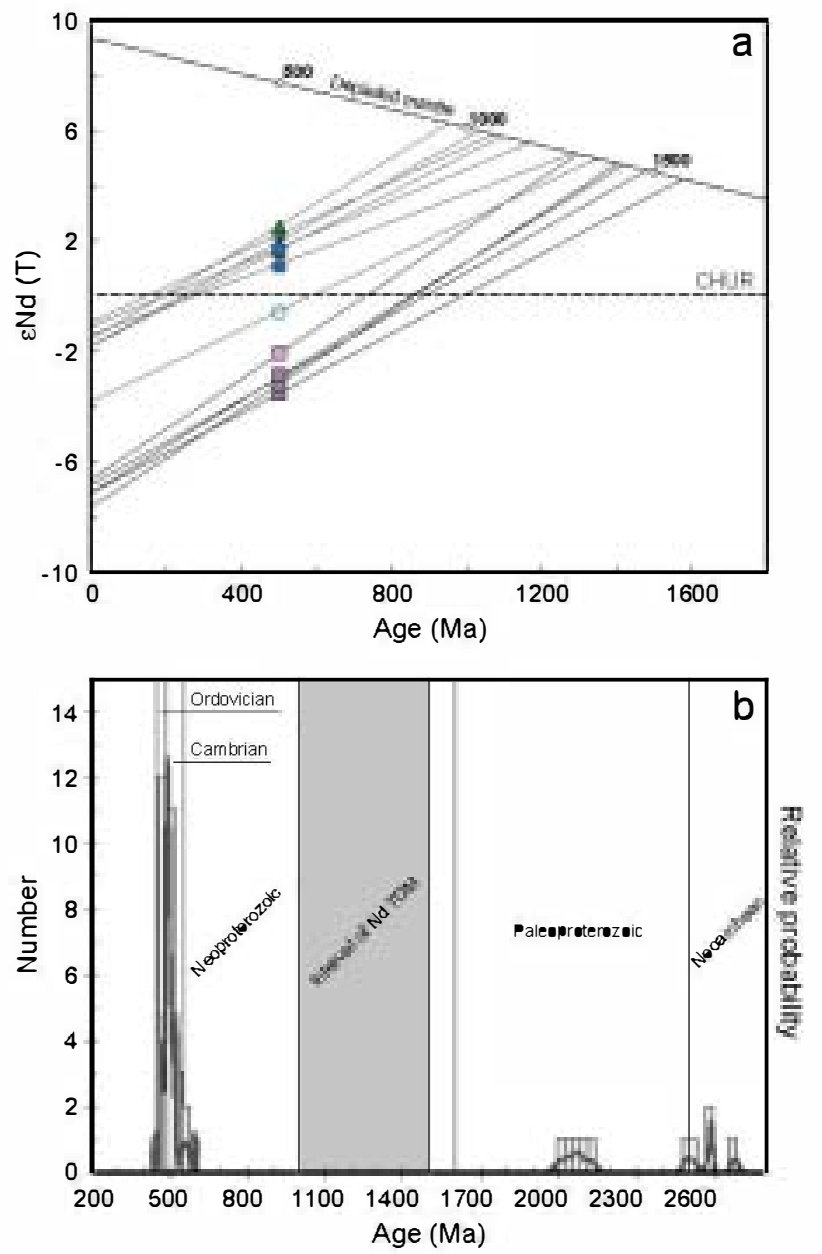

Fig. 9. a) $\varepsilon_{\text {Na }}$ versus age diagram. Depleted mantle evolution calculated according to DePaolo (1981). b) Probability density plot with the ages obtained from inherited grains and xenocrystic cores. The gray field represents the model ages calculated from the Nd isotopes (TDM). 
$\left({ }^{87} \mathrm{Sr} /{ }^{86} \mathrm{Sr}\right)_{i}$ ratio, owing to crustal contamination during its generation. The relatively high values in $\mathrm{Sr}_{\mathrm{i}}$ and negative values in $\varepsilon \mathrm{Nd}$ of the granodioritic orthogneisses suggest that these rocks have a clear crustal influence in their generation, in contrast to the tonalitic orthogneisses and uncontaminated metagabbronorites, where the influence component is negligible and their origin can be related to basic magmas extracted from the mantle or from a basic lower continental crust.

In Fig. 8 we have also included the pattern followed by the Andean batholiths, studied by Rogers and Hawkesworth (1989) and the Iachlan Fold Belt batholiths (I-type) studied by McCulloch and Chappell (1982). It is evident that the Corredoiras metaigneous rocks are very similar to Andean batholiths, strengthening the hypothesis that these rocks were generated in a subduction zone where continental crust already existed.

Calculated depleted mantle model ages (TDM, see Table 2 and Fig. 9a; DePaolo, 1981) for the granodioritic orthogneisses range between 1300 and $1600 \mathrm{Ma}$, whereas tonalitic orthogneisses and metagabbros have slightly younger model ages (1000-1300 Ma). The absence of inherited zircon with these ages (Fig. 9b), the presence of older inherited zircon and the varied lithological constitution of the Corredoiras massif (basic to felsic rocks) suggest that the $\mathrm{Nd}$ model ages represent a mixture between juvenile material and
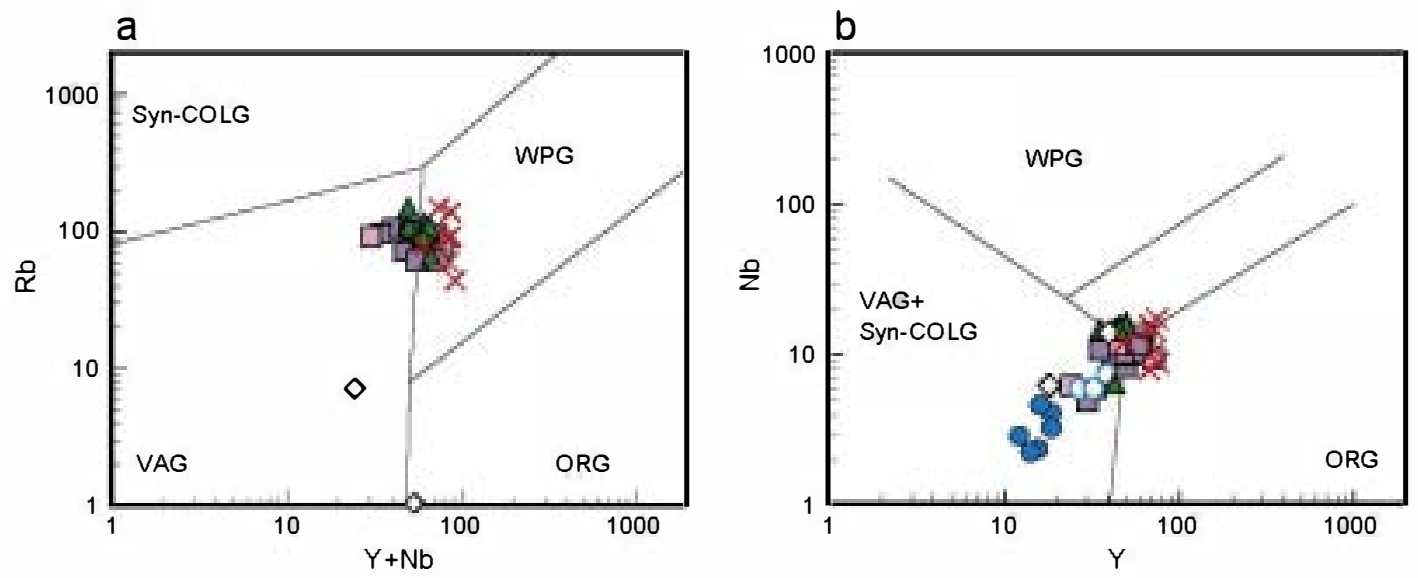

Syn-COLG = Syncollisional granites WPG $=$ within plate granites

$V A G=$ volcanic arc granites $O R G=$ oceanic ridge granites

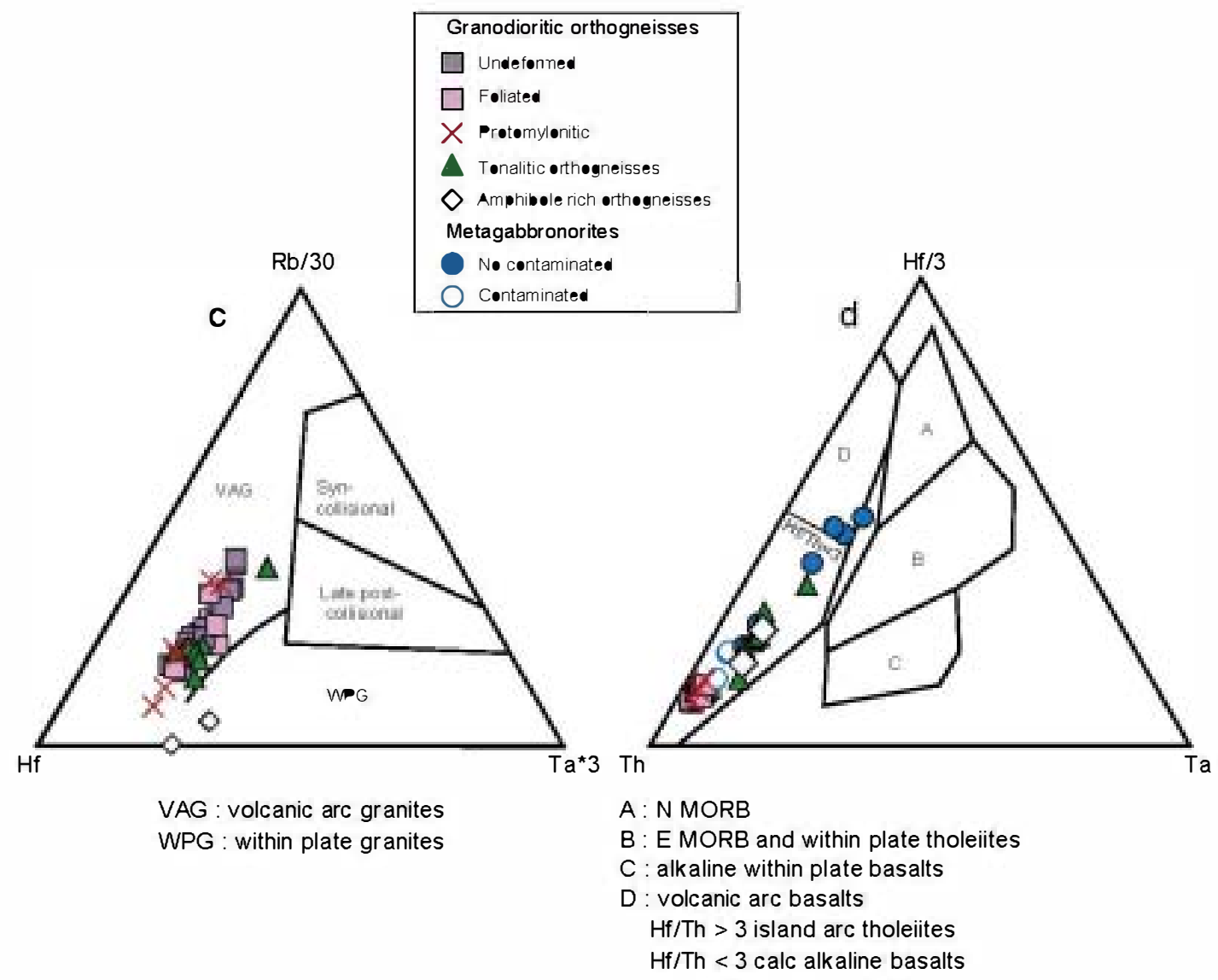

Fig. 10. Trace element discrimination diagrams for the metaigneous rocks of Corredoiras massif. a) Rb-Y $+\mathrm{Nb}$ and b) Nb-Y diagrams after Pearce et al. (1984); $\mathrm{c}$ ) Rb-Hf-Ta diagram (Harris et al., 1986); d) Hf-Th-Ta diagram (Wood, 1980). 
melting of an old crust. The older model ages of the granodioritic orthogneisses would indicate a higher proportion of old crustal components in the mixture, whereas more juvenile material would be necessary to explain the younger model ages of the tonalites and gabbros.

\section{Tectonic setting}

Calc-alkaline volcanic and plutonic rocks have long been recognized as the products of arc magmatism occurring at convergent plate boundaries. The plutonic roots of those arc systems are of ten exposed in old terranes, generally following collision/accretion, uplift and erosional events. To determine the tectonic setting of the Corredoiras massif, we have used standard discrimination diagrams for granitoids, i.e., $\mathrm{Y}+\mathrm{Nb}$ vs. Rb, Y vs $\mathrm{Nb}$ (Pearce et al., 1984) and $\mathrm{Rb} /$ 30-Hf-Ta 30 (Harris et al., 1986). In the Y + Nb vs. Rb and Yvs. Nb diagrams (Fig. 10a and b, respectively), the Corredoiras felsic and intermediate rocks plot in the volcanic arc granites field (VAG) close to the ocean ridge granites (ORG) or the within plate granites (WPG). $\mathrm{The} \mathrm{Rb} / 30-\mathrm{Hf}-\mathrm{Ta} 30$ diagram better discriminates the tectonic setting for these rocks (Fig. 10c); all of the felsic and intermediate metaigneous rocks plot in the volcanic arc granites field. We have also plotted all the Corredoiras rocks in the Hf/3-Th-Ta diagram (Wood, 1980) (Fig. 10d), which allows an accurate discrimination of
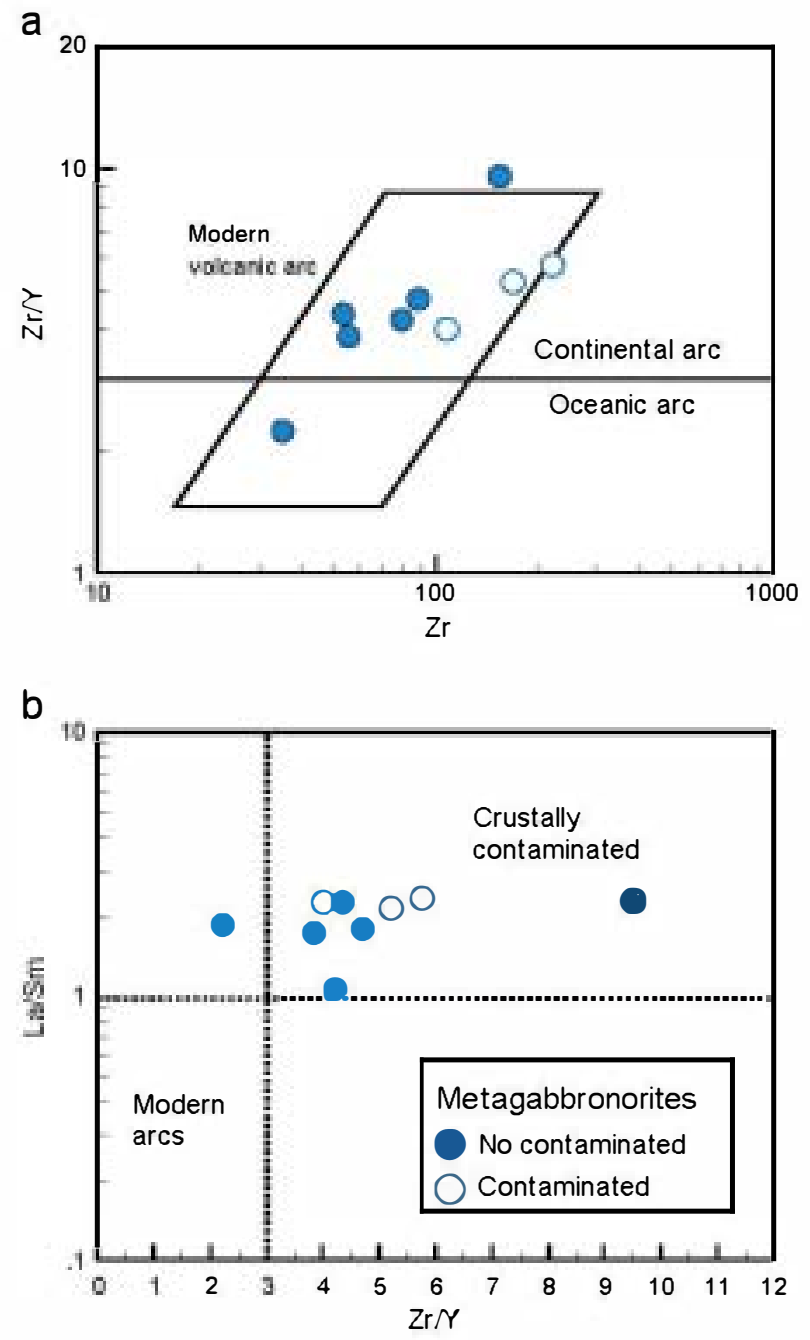

Fig. 11. a) $\mathrm{Zr} / \mathrm{Y}-\mathrm{Zr}$ diagram (Pearce, 1983) and b) $\mathrm{La} / \mathrm{Sm}-\mathrm{Zr} / \mathrm{Y}$ diagram (Bolhar et al., 2003) for metagabbronorites samples. subduction related rocks. Most of the samples plot in the volcanic arc field with calc-alkaline affinity $(\mathrm{Hf} / \mathrm{Th}<3)$, except for three gabbros that have tholeiitic affinity ( $\mathrm{Hf} / \mathrm{Th}>3)$.

In the $\mathrm{Zr} / \mathrm{Y}$ vs. $\mathrm{Zr}$ diagram (Pearce, 1983), the metagabbronorites plot in the continental island arc field (Fig. 11a). In the $(\mathrm{La} / \mathrm{Sm})_{N}$ vs. $\mathrm{Zr} / \mathrm{Y}$ diagram (Fig. 11b), where the $\mathrm{La} / \mathrm{Sm}$ ratio is normalized to primitive mantle (Bolhar et al., 2003), all of the Corredoiras metagabbronorites plot as crustally contaminated rocks, which is consistent with their low $\mathrm{MgO}$ and $\mathrm{Cr}$ content and relatively high $\mathrm{Na}_{2} \mathrm{O}$ and $\mathrm{K}_{2} \mathrm{O}$ contents.

Trace element abundances for each groupof Corredoiras samples can be normalized to the average composition of rocks from a specific geodynamic setting to determine more accurately their origin. We have used the average ORG composition from Pearce et al. (1984) for all the orthogneisses, whereas the basic rocks have been normalized to the $\mathrm{N}$ MORB composition (Pearce, 1996). All orthogneisses are characterized by a highly fractionated element pattem (Fig. 12), with a strong enrichment in Th and slightly enriched in Ce and Hf compared to ORG. They display significant negative anomalies in $\mathrm{Ta}, \mathrm{Nb}$ and $\mathrm{Zr}$, which together with their low contents in $\mathrm{Y}$ and $\mathrm{Yb}$ are characteristic of granitoids generated in volcanic arc or subduction zones. The amphibolerich orthogneisses also have negative anomalies in $\mathrm{Ta}$ and $\mathrm{Nb}$ and the same low content in $\mathrm{Yb}$. Comparing our samples with the average andesite-dacite-rhyolite association from island and continental arcs according to Drummond et al. (1996), the granodioritic and tonalitic orthogneiss pattems are similar to the continental arc association (Fig. 12d), even though the Corredoiras orthogneisses are slightly enriched in most of the elements. Amphibole-rich orthogneisses plot between the island and continental arc pattems. In a similar diagram, the metagabbros pattern (Fig. 13) resembles continental arc basalts with high K (Pearce, 1996). They also show a slight enrichment in Th, more pronounced in the contaminated gabbros. All the metagabbros have a negative anomaly in $\mathrm{Nb}$, which is typical of igneous rocks generated in a subduction zone.

\section{Discussion and conclusions}

The Corredoiras massif metaigneous rocks have geochemical, U$\mathrm{Pb}$ and $\mathrm{Sm}-\mathrm{Nd}$ compositions indicating that they belong to the Cambro-Ordovician (520-495 Ma) magmatic episode recorded in the upper units of the allochthonous complexes (Abati et al., 1999, 2007; Santos et al., 2002). The geochemical characteristics point out that the Corredoiras metaigneous rocks have been generated in a magmatic arc and that continental crust was involved in the origin of the magma. This hypothesis is also backed up by the presence of metasedimentary enclaves and biotite-rich microenclaves within them. Major element geochemistry resemble I-type granite features (high $\mathrm{K}_{2} \mathrm{O}$ and $\mathrm{Na}_{2} \mathrm{O}$ contents, negative slope in $\mathrm{P}_{2} \mathrm{O}_{5}$ with increasing $\mathrm{SiO}_{2}$ and weak peraluminous character). Their incompatible elements enrichment, negative anomalies in $\mathrm{Nb}, \mathrm{Ta}, \mathrm{Sr}, \mathrm{P}$ and Ti are typical of continental arcs. High $\mathrm{Th}$ values and low $\mathrm{Ba} / \mathrm{Th}$ ratios indicate a sediment participation or continental crust contamination in the magmas that originated the Corredoiras rocks. A negative $\varepsilon N d$ value in the granodioritic orthogneisses may be also considered as evidence for the involvement of felsic crustal material during the genesis of these rocks. On the contrary, tonalitic orthogneisses and metagabbros have a positive $\varepsilon N d$ value that can be produced by mantle derived melts or by lower crustal melts.

The presence of inherited zircons that also appear in other igneous rocks of the upper units, suggests that this continental crust could belong to the West African Craton. Detrital zircon ages from low grade metasediments of the upper units (Martínez Catalán et al., 2009) also record the major crust forming events in NW Africa: this evidence points to a common basement for the upper units, and suggests that the island arc was ensialic and may represent a peri-Gondwanan fragment which drifted away opening the Rheic Ocean. Martínez 
a) granodioritic orthogneisses

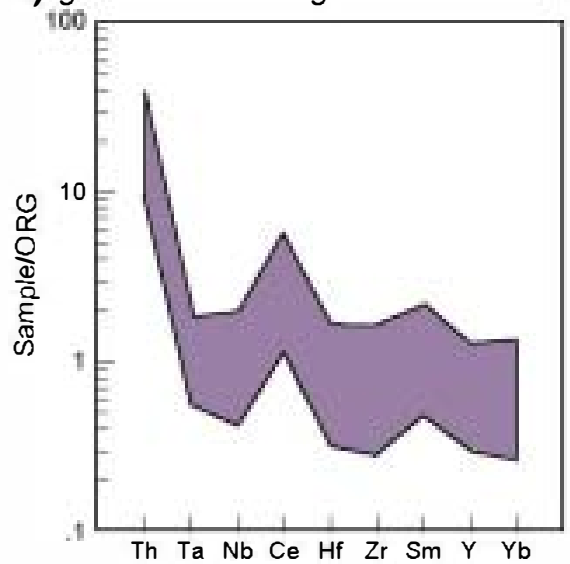

C) amphibole rich orthogneisses

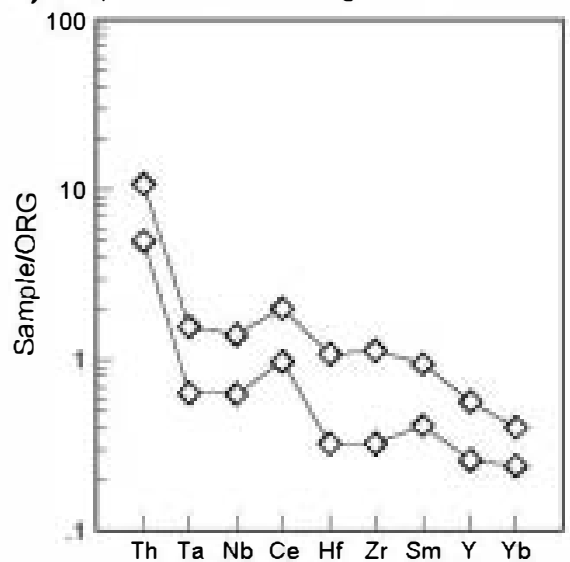

b) tonalitic orthogneisses

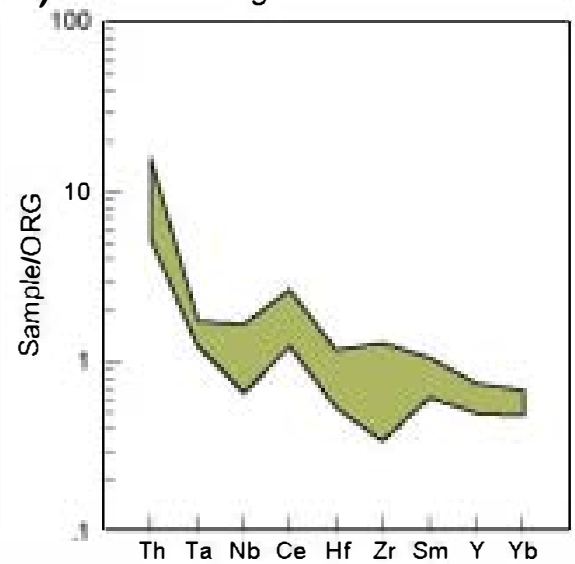

d) average values

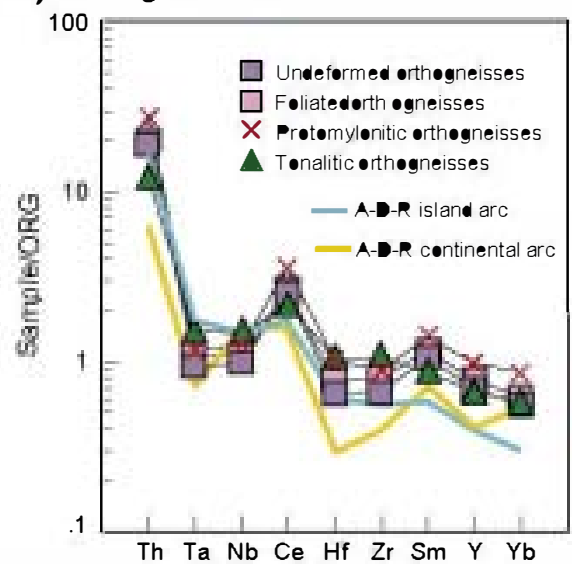

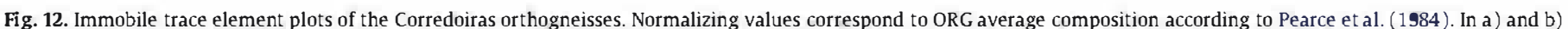

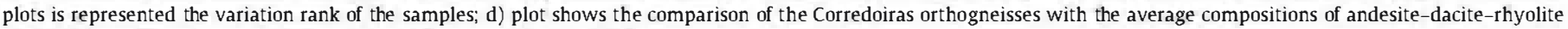
(A-D-R) from island arcs and continental arcs (Drummond et al., 1996).

Catalán et al. (2007) proposed a model reconstructing the tectonic evolution of the allochthonous complexes from Galicia. In this model can be seen that around $500 \mathrm{Ma}$ a Peri-Gondwanan terrane is detached from the Gondwana margin by slab roll-back and an arcrelated magmatic activity during Late Cambrian-Early Ordovician.

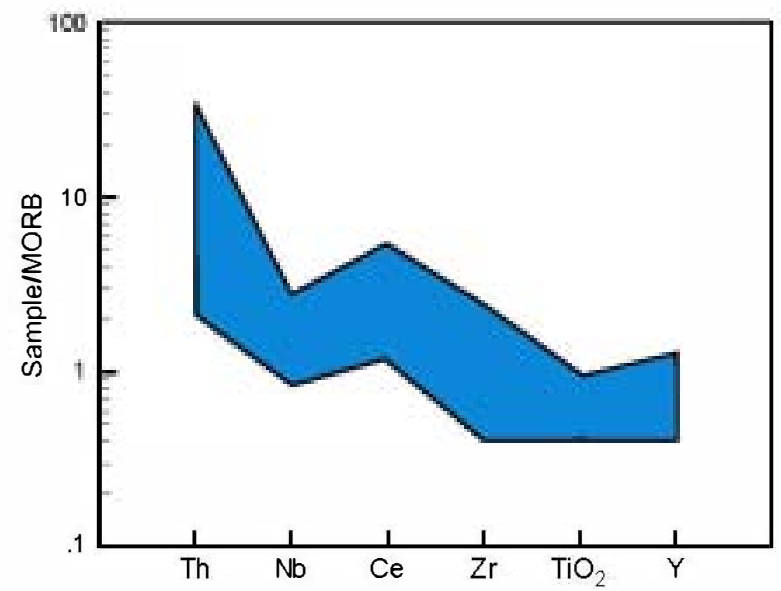

Fig. 13. Immobile trace element plot of the Corredoiras metagabbros. Normalizing values correspond to N-MORB average composition according to Pearce (1996). Shading zone is the compositional range for all samples.
We propose that the magmatic rocks of the Corredoiras massif were generated in this realm, probably located in the arc inner zone, where the magmas can be strongly influenced by the continental crust (Fig. 14).

Later on, this arc was involved in the Variscan collision. A CambroOrdovician arc-related metamorphism was preserved in the intermediate-P units, but was overprinted by a Silurian-Early Devonian tectonometamorphic event in the high-P and high-T units. This event involved subduction of part of the arc, as a consequence of its accretion to Laurussia while the Rheic Ocean was still open.

Supplementary materials related to this article can be found online at doi:10.1016/j.lithos.2011.11.005.

\section{Acknowledgments}

Financial support for this research has been provided by the Spanish project CGL 2007-65338-CO2-01/BTE (Ministerio de Ciencia e Innovación), and by the Universidad Complutense Research Group 910129. Wayne Premo and Joe Wooden are kindly acknowledged for their assistance during the Sm-Nd and the SHRIMP analytical sessions, respectively. Special thanks to Isabelle Brownfield of the U.S. Geological Survey (USGS) for her assistance in obtaining imaging of zircons using the scanning electron microscope in the USGS Denver Microbeam Laboratory. We thank Antonio Castro and an anonymous referee for their detailed and constructive reviews which did much improve the manuscript. 


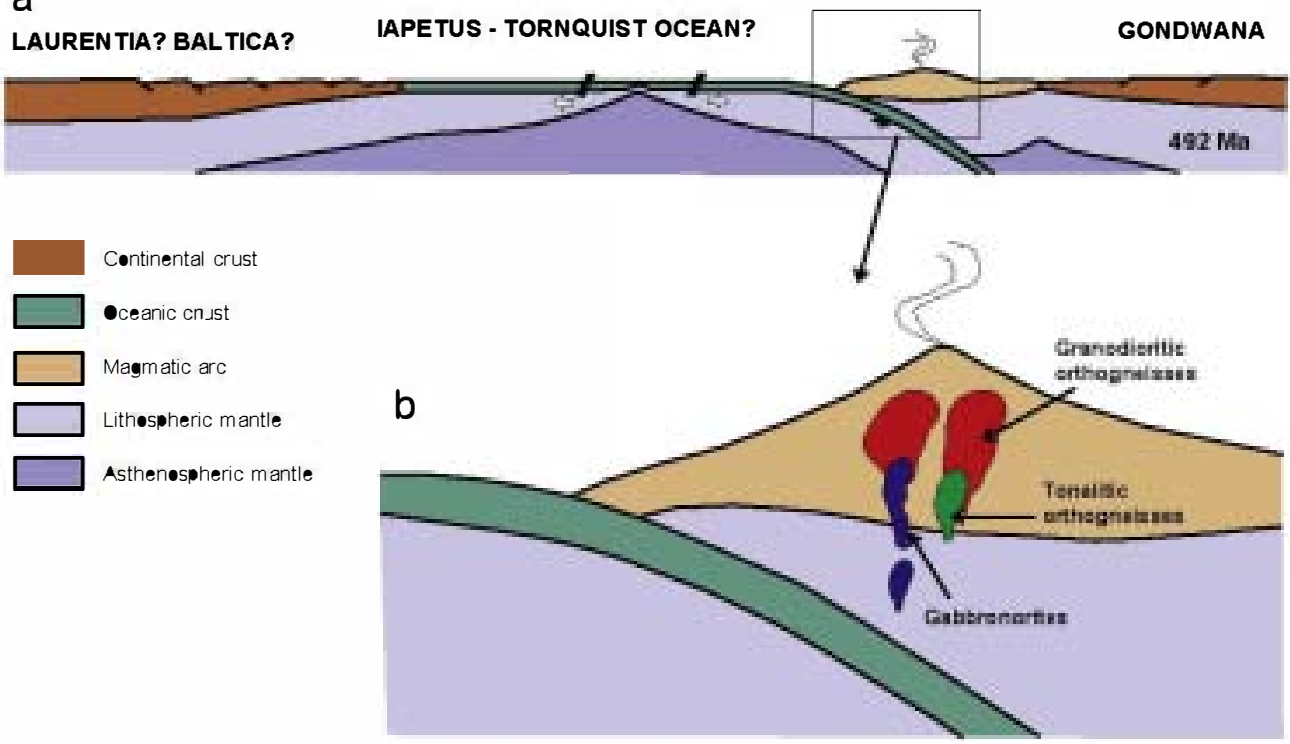

Fig. 14. Geodynamic sketch showing the magma generation of the Corredoiras metaigneous rocks. a: General location of the magmatic arc in the Gondwana margin. b: Sketch of the possible source of the Corredoiras metaigneous rocks: granodioritic orthogneisses probably were generated in the arc crust, tonalitic orthogneisses could be either generated in the lower crust or in the mantle, and gabbronorites were generated in the mantle and some of them were contaminated by either the arc crust or by a granodioritic magma.

\section{References}

Abati, J., Dunning, G.R, Arenas, R., Díaz García, F., González Cuadra, P., Martínez Catalán, J.R., Andonaegui, P., 1999. Early Ordovician orogenic event in Galicia (NW Spain): evidence from $\mathrm{U}-\mathrm{Pb}$ ages in the uppermost unit or the Órdenes Complex. Earth and Planetary Science Letters 165, 213-228.

Abati, J., Arenas, R., Martínez Catalán, J.R., Díaz García, F., 2003. Anticlockwise P-T path of granulites from Monte Castelo gabbro (Órdenes complex, NW Spain). Journal of Petrology 44, 305-327.

Abati,J., Castiñeiras, P., Arenas, R., Fernández-Suárez,J., Gómez-Barreiro, J., Wooden, J., 2007. Using SHRIMP zircon dating to unravel tectonothermal events in arc environments. The early Palaeozoic arc of NW Iberia revisited. Terra Nova 19, 432-439.

Abati, J., Gerdes, A, Fernández-Suárez, J., Arenas, R, Whitehouse, M.J. Díez, Fernández, R., 2010. Magmatism and early-Variscan continental subduction in the northern Gondwana margin recorded in zircons from the basal units of Galicia, NW Spain. Geological Society of America Bulletin 122, 219-235.

Andonaegui, P., González del Tánago, J., Arenas, R., Abati, J., Martínez Catalán, J.R., Peinado, M. Díaz Garćia, F., 2002. Tectonic setting of the Monte Castelo Gabbro (Ordenes Complex, NW Iberian Massif : : Evidencefor an arc-related terranein the hangingwall to the Variscan suture, in: Martínez Catalán, J.R., Hatcher, RD. Jr., Arenas, R., Díaz García, F. (Eds.), Variscan-Appalachian dynamics: The building of the late Paleozoic basement. Geological Society of America Special Paper 364, pp. 37-56.

Arenas, R., Gil Ibarguchi,J.L, González Lodeiro, F., Klein, E., Martínez Catalán, J.R., Ortega Gironés, E., Pablo Maciá, J.G. de., Peinado, M., 1986. Tectonostratigraphic units in the complexes with mafic and related rocks of the NW of the Iberian Massif. Hercynica ll, 87-110.

Arenas, R, Rubio Pascual, F.J., Díaz García, F., Martínez Catalán, J.R., 1995. High-pressure micro-inclusions and development of an inverted metamorphic gradient in the Santiago Schists (Órdenes Complex, NW Iberian Massif, Spain): evidence of subduction and syn-collisional decompression. Journal of Metamorphic Geology 13, 141-164.

Arenas, R., Martínez Catalán, J.R., Díaz García, F., Rubio Pascual, F.J., 1997. P-T evolution of eclogites from the Agualada Unit (Órdenes Complex, NW Iberian Massif, Spain): implications for crustal subduction. Lithos 40, 221-242.

Arenas, R, Martínez Catalán, J.R, Sánchez Martínez, S., Diaz García, F., Abati, J., Fernández-Suárez,J., Andonaegui, P., Gómez-Barreiro, J., 2007a. Paleozoic ophiolites in the Variscan suture of Galicia (northwest Spain): distribution, characteristics and meaning, in: Hatcher, R.D. Jr., Carlson, M.P., McBride, J.H., Martínez Catalán, J.R. (Eds.), 4D framework of Continental Crust. Geological Society of America Memoir 200, pp. 425-444

Arenas, R., Martínez Catalán, J.R., Abati, R., Sánchez Martínez, S. (Eds.), 2007b. The rootless Variscan suture of NW Iberia (Galicia, Spain). The International Geoscience Programme IGCP 497: "The Rheic Ocean: Its origin, evolution and correlatives". Galicia Meeting 2007. Field trip guide \& Conference abstracts. Publicaciones del Instituto Geológico y Minero de España.

Arenas, R., Martínez Catalán, J.R., Sánchez Martínez, S., Fernández-Suárez, J., Andonaegui, P., Pearce, J.A., Corfu, F., 2007a. The Vila de Cruces Ophiolite: a remnant of the early Rheic Ocean in the Variscan suture of Galicia (NW Iberian Massif). Journal of Geology 115, 129-148.

Black, L.P., Kamo, S.L., Allen, C.M., Davis, D.W., Aleinikoff, J.N., Valley, J.W., Mundil, R., Campbell, LH., Korsch, R.J., Williams, I.S., Foudoulis, C., 2004. Improved ${ }^{206} \mathrm{~Pb} /$ ${ }_{23^{3} \mathrm{U} \text { microprobe geochronology by the monitoring of a trace-element-related }}$ matrix effect, SHRIMP, ID-TIMS, EIA-ICP-MS and oxygen isotope documentation for a series of zircon standards. Chemical Geology 205, 115-140.

Bolhar, R., Woodhead, J.D., Hergt, J.M., 2003. Continental setting inferred for emplacement of the 2.9-2.7 Ga Belingwe Greenstone Belt, Zimbabwe. Geology 31, 295-298.

Brown, G.C., Thorpe, R.S., Webb, P.C, 1984 . The geochemical characteristics in contrasting arcs and comments on magma sources. Journal of the Geological Society of London 141, 413-426.

Castiñeiras, P., 2005. Origen y evolución tectonotermal de las Unidades de O Pino y Cariño (Comple jos Alóctonos de Galicia). Nova Terra 28, (In Spanish).

Castiñeiras, P., Díaz García, F., Gómez Barreiro, J., 2010. REE-assisted U-Pb zircon age (SHRIMP) of an anatectic granodiorite: constraints on the evolution of the A Silva granodiorite, Iberian allochthonous complexes. lithos 116, 153-166.

Chappell, B.W., 1999. Aluminium saturation in I and S-type granites and the characterization of fractionated haplogranites. 1ithos 46, 535-551

Dallmeyer, R.D., Martínez Catalán,J.R., Arenas, R., Gil Ibarguchi,J.L, Gutiêrrez Alonso, G., Farias, P., Aller, J., Bastida, F., 1997 . Diachronous Variscan tectonothermal activity in the NW Iberian Massif: evidence from ${ }^{40} \mathrm{Ar} /{ }^{39} \mathrm{Ar}$ dating of regional fabrics. Tectonophysics 277, 133-144.

DePaolo, D.J., 1981. Neodymiun isotopes in the Colorado Front range and crust-mantle evolution in the Proterozoic. Nature 291, 193-196.

Davidson, J.P., 1996. Deciphering mantle and crust signatures in subduction zone magmantism, in: Bebout, G.E., Scholl, D., Kirby, S. \& Platt, J.P. (Eds.), Subduction: top to bottom. American Geophysical Union, Geophysical Monograph 96, pp. 251-262.

Díaz García, F., Arenas, R., Martínez Catalán, J.R, González del Tánago, J., Dunning, G. 1999a. Tectonic evolution of the Careón ophiolite (Northwest Spain): a remnant of oceanic lithosphere in the Variscan belt. Journal of Geology 107, 587-605.

Díaz García, F., Martínez Catalán, J.R., Arenas, R., González Cuadra, P., 1999b. Structural and kinematic analysis of the Corredoiras detachment: evidence for early Variscan orogenic extension in the Órdenes Complex, NW Spain. International Journal of Earth Sciences 88,337-351.

Díez Fernández, R., Castiñeiras, P., Gómez Barreiro, J., 2011. Age constraints on Lower Paleozoic convection system: magmatic events in the NW Iberian Gondwana margin. Gondwana Research, in press. doi:10.1016/j.gr.2011.07.028

Drummond, M.S., Defant, M.J, Kepezhinskas, P.K., 1996. Petrogenesis of slab-derived trondh jemite-tonalite-dacite/adakite magmas. Transactions of the Royal Society of Edinburgh 87, 205-215.

Fernández Suárez, J., Díaz García, F., Jeffreis, T.E., Arenas, R, Abati, J., 2003. Constrains on the provenance of the uppermost allochthonous terrane of the NW Iberian Massif: inferences from detrital zircon U-Pb ages. Terra Nova 15, 138-144.

Fernández Suárez, J., Arenas, R., Abati, J., Martínez Catalán, J.R., Whitehouse, M.J., Jeffries, T.E., 2007. U-Pb chronometry of polimetamorphic high-pressure granulites: an example from the allochthonous terranes of the NW Iberian Variscan belt, in: Hatcher, RD. Jr., Carlson, M.P., McBride, J.H., Martínez Catalán, J.R (Eds.), 4D framework of Continental Crust. Geological Society of America Memoir 200, pp. 469-488.

Frost, B.R., Barnes, C.G., Collins, W.J., Arculus, R.J., Ellis, D.J., Frost, C.D., 2001. A geochemical classification for granitic rocks. Journal of Petrology 42, 2033-2048.

Fuenlabrada, J.M., Arenas, R., Sánchez Martínez, S., Díaz García, F., Castiñeiras, P., 2010. A peri-Gondwanan arc in NW Iberia I: isotopic and geochemical constraints on the origin of the arc - a sedimentary approach. Gondwana Research 17, 338-351.

Galán, G., Marcos, A, 1997. Geochemical evolution of high-pressure mafic granulites from the Bacariza formation (Cabo Ortegal Complex, NW Spain): an example of a heterogeneous lower crust. Geologische Rundschau 86, 539-555. 
Gil Ibarguchi, J.I., Mendia, M., Girardeau, J., Pecaut, J.J., 1990. Petrology of eclogites and clinopyroxene-garnet metabasites from the Cabo Ortegal Complex (northwestern Spain). lithos 25, 133-162.

González Cuadra, P., 2007. La Unidad de Corredoiras (Comple jo de Órdenes, Galicia): Evolución estructural y metamórfica. Nova Terra 33, 254 p. (In Spanish).

Gorton, M.P., Schandl, E.S., 2000. From continents to islands arcs: a geochemical index of tectonic setting for arc-related and within-plate felsic to intermediate volcanic rocks. Canadian Mineralogist 38, 1065-1073.

Harris, N.B.W., Pearce J.A., Tindle, AG., 1986. Geochemical characteristics of collision zone magmatism, in: Coward, M.P., Reis, AC. (Eds.), Collision tectonics. Special Publications of the Geological Society of London 19, pp. 67-81.

Hastie, A.R., Kerr, A.C, Pearce, J.A., Mitchell, S.F., 2007. Classification of altered volcanic island arc rocks using immobile trace elements: development of the Th-Co discrimination diagram. Journal of Petrology 48, 2341-2357.

Hawkesworth, C., Turner, S., Peate, D., McDermott, F., Van Calsteren, P., 1997. Elemental $U$ and Th variations in island arc rocks: implications for $U$-series isotopes. Chemical Geology 139, 207-221.

Hine, R., Williams, I.S., Chapell, B.W., White, A.J.R., 1978. Contrast between 1- and S-type granitoids of the Kosciusko batholith. Journal of the Geological Society of Australia $25,219-234$.

Ireland, T.R., Williams, I.S., 2003. Considerations in zircon geochronology by SIMS, in: Hanchar, J.M., Hoskin, P.W.O. (Eds.), Zircon. Mineralogical Society of America. Reviews in Mineralogy and Geochemistry 53, pp. 215-241.

Irvine, T.N., Baragar, W.R.A., 1971. Aguide to the chemical classification of the common volcanic rocks. Canadian Journal of Earth Sciences 8, 523-548.

Kawate, S., Arima, M., 1998. Petrogenesis of the Tanazawa plutonic complex, central Japan: exposed felsic middle crust of the Izu-Bonin-Mariana arc. Island Arc 7 $342-358$

Ludwig, K.R., 1998. On the treatment of concordant uranium-lead ages. Geochimica et Cosmochimica Acta 62, 665-676.

Ludwig, K.R., 2002. SQUID 1.02, a user's manual. Berkeley Geochronology Center Special, Publication 2

Ludwig, K.R., 2003. ISOPLOT/Ex, version 3. Berkeley Geochronology Center Special Publication, A Geochronological Toolkit for Microsoft Excel. 4.

Lugmair, G.W., Scheinin, N.B., and Marti, K., 1975. Sm-Nd age and history of Apollo 17 basalt 75075: evidence for early differentiation of the lunar exterior. Sixth Lunar Science Conference Proceedings, 1419-1429.

Marchesi, C., Garrido, C. J., Bosch, D., Proenza, J.A., Gervilla, F., Monie, P., Rodríguez-Vega A. 2007. Geochemistry of Cretaceous magmatism in eastern Cuba: recycling of North American continental sediments and implications for subduction polarity in the Greater Antilles paleo-arc. Journal of Petrology 48, 1813-1840.

Martínez Catalán, J.R., Arenas, R., Díaz García, F., Rubio Pascual, F.J., Abati, J., Marquínez, J. 1996. Variscan exhumation of a subducted Paleozoic continental margin: the basal units of the Órdenes Complex, Galicia NW Spain. Tectonics 15, 106-121.

Martínez Catalán, J.R., Díaz García, F., Arenas, R., Abati, J., Castiñeiras, P., González Cuadra, P., Gómez Barreiro, J., Rubio Pascual, F.J., 2002. Thrusts and detachment systems in the Órdenes Complex (northwestern Spain): Implications for the Variscan-Appalachian geodynamics, in: Martínez Catalán, J.R., Hatcher, R.D. Jr., Arenas, R., Díaz García F. (Eds.), Variscan-Appalachian dynamics: The building of the Paleozoic basement Geological Society of America Special Paper 364, pp. 163-182

Martínez Catalán,J.R., Arenas, R., Díaz García, F., Gómez Barreiro, J., González Cuadra, P. Abati, J., Castiñeiras, P., Fernández-Suárez, J., Sánchez Martínez, S., Andonaegui, P. Díez Montes, A, González Clavijo, E., Rubio Pascual, FJ. Valle Aguado, B. 2007. Space and time in the tectonic evolution of the northwestern Iberian Massif. Implications for the comprehension of the Variscan belt, in: Hatcher, R.D. Jr., Carlson, M.P., McBride, J.H., Martínez Catalán, J.R. (Eds.), 4D framework of Continental Crust. Geological Society of America Memoir 200, pp. 403-423.

Martínez Catalán, J.R., Arenas, R., Abati, J., Sánchez Martínez, S., Díaz García, F., Fernández Suárez, J., González Cuadra, P., Castiñeiras, P., Gómez Barreiro, J., Díez Montes, A, González Clavijo, E., Rubio Pascual, F.J., Andonaegui, P., Jeffries, T., Alcock, J.E. Díez Fernández, R., López Carmona, A, 2009. A rootless suture and the loss of roots of a mountain chain: the Variscan belt of NW Iberia. Comptes Rendues Geoscience $341,114-126$.

Matte, Ph., 1991. Accretionary history and crustal evolution of the Variscan belt in Western Europe. Tectonophysics 196, 309-337.

McCulloch, M.T., Chappell, B.W., 1982. Nd isotopic characteristics of S-and I-type granites Earth and Planetary Science Letters 58, 51-64.

MendiaAranguren, M.S., 2000. Petrología de la Unidad Eclogítica del Comple jo de Cabo Ortegal (NW de España). Nova Terra 16. (In Spanish).

Montero, P., Bea, F., Corretgê, L.G., Floor, P., Whitehouse, M.J., 2009. U-Pb ion micro probe dating and $\mathrm{Sr}$ and $\mathrm{Nd}$ isotope geology of the Galiñeiro Igneous Complex. A model for the peraluminous/peralkaline duality of the Cambro-Ordovician magmatism of Iberia. lithos 107, 227-238.

Münker, C., Wöner, G., Yogodzinski, G., Churikova, T., 2004. Behaviour of high field strength elements in subduction zones: constraints from Kamchatka-Aleutianas arc lavas. Earth and Planetary Science Letters 224, 275-293.

Nakamura, N., 1974. Determination of REE, Ba, Fe, Mg, $\mathrm{Na}$, and $\mathrm{K}$ in carbonaceous and ordinary chondrites. Geochimica et Cosmochimica Acta 38, 757-775.

Ordóñez Casado, B., 1998. Geochronological studies of the Pre-Mesozoic basement of the Iberian Massif: the Ossa Morena zone and the Allochthonous Complexes within the Central Iberian zone. Ph.D. Thesis. Swiss Federal Institute of Technology Zürich.
Ordonez Casado, B., Gebauer, D., Schäfer, H.J., Gil Ibarguchi, J.L, Peucat, J.J., 2001. A single Devonian subduction event for the HP/HT metamorphism of the Cabo Ortegal complex within the Iberian Massif. Tectonophysics 332, 359-385.

Pearce, J.A., 1983. Role of the sub-continental lithosphere in magma genesis at active continental margins. In: Hawkeswoth, C.J., Norry, M.J. (Eds.), Continental Basalts and Mantle Xenoliths. Shiva, Nantwich, pp. 230-249.

Pearce, J.A., 1996. A users guide to basalt discrimination diagrams, in: Wyman, D.A. (Ed.), Trace element geochemistry of volcanic rocks: applications for massive sulphide exploration. Geological Association of Canada, Short Course Notes 12, pp 79-113.

Pearce, J.A., 2008. Geochemical fingerprinting of oceanic basalts with applications to ophiolite classification and the search for Archean oceanic crust. Lithos 100, 14-48.

Pearce, J.A., Harris, N.B.W., Tindle, AG., 1984. Trace element discrimination diagrams for tectonic interpretation of granitic rocks. Journal of Petrology 25, 956-983.

Peccerillo, R, Taylor, S.R., 1976. Geochemistry of Eocene calc-alkaline volcanic rocks from the Kastamonu area, northern Turkey. Contributions to Mineralogy and Petrology 58, 63-81.

Pidgeon, R.T., Furfaro, D., Kennedy, A.K., Nemchin, A.A., Van Bronswjk, W., 1995. Calibration of Zircon Standards for the Curtin SHRIMP ll. U.S. Geological Survey Circular. 1107.

Pin, C, 1990. Variscan oceans: ages, origins and geodynamic implications inferred from geochemical and radiometric data. Tectonophysics $177,215-227$.

Pin, C., Ortega Cuesta, L.A., Gil Ibarguchi, J.I., 1992. Mantle-derived, early Paleozoic A type metagranitoids from the NW Iberian Massif: Nd isotope and trace element constraints. Bulletin de la Societê Géologique de France 163, 483-494.

Pin, C., Paquette, J.L., Santos Zalduegui, J.F., Gil Ibarguchi, J.I., 2002. Early Devonian supra-subduction zone ophiolite related to incipient collisional processes in the Western Variscan Belt: The Sierra de Careón unit, Órdenes Complex, Galicia, in: Martínez Catalán, J.R., Hatcher, RD. Jr., Arenas, R., Díaz García, F. (Eds.), VariscanAppalachian dynamics: The building of the Paleozoic basement. Geological Society of America Special Paper 364, pp. 57-71.

Premo, W.R., Loucks, R.R., 2000. Age and Pb-Sr-Nd isotopic systematics of plutonic rocks from the Green Mountain magmatic arc, southeastern Wyoming: isotopic characterization of a Paleoproterozoic island arc system. Rocky Mountain Geology $35,51-70$

Rodríguez, J., Cosca, MA., Gil Ibarguchi, J.L, Dallmeyer, R.D., 2003. Strain partitioning and preservation of ${ }^{40} \mathrm{Ar} /{ }^{39} \mathrm{Ar}$ ages during Variscan exhumation of a subducted crust (Malpica-Tui complex, NW Spain). lithos 70, 111-139.

Rodríguez,J., Paquette, J.L., Gil Ibarguchi, J.I., 2007. U-Pb dating of lower Ordovician alkaline magmatism in the Gondwana margin (Malpica-Tui Complex, Iberian Massif): Latest continental events before oceanic spreading, in: Arenas, R., Martínez Catalán, J.R., Abati, J., Sánchez Martínez, S. (Eds.), The rootless Variscan suture of NWIberia (Galicia, Spain). The Intemational Geoscience Programme IGCP 4 97: "The Rheic Ocean: Its origin, evolution and correlatives". Galicia Meeting 2007. Field trip guide \& Conference abstracts. Publicaciones del Instituto Geológioo y Minero de España. pp. 163-164.

Rodríguez Aller, J., 2005. Recristalización y deformación de litologías supracorticales sometidas a metamorfismo de alta presión (Complejo de Malpica - Tuy, NO del Macizo Ibérico). Nova Terra 29. (In Spanish)

Rogers, G., Hawkesworth, C.J., 1989. A geochemical traverse across the North Chilean Andes: evidence for crustal generation from the mantle wedge. Earth and Planetary Science Letters $91,271-285$

Rojas-Agramonte, Y., Neubauer, F., Kroner, A, Wan, Y.S., Liu, D.Y., García-Delgado, D.E., Handler, R., 2004. Geochemistry and early Paleogene SHRIMP zircon ages for island-arc granitoids of Sierra Maestra, southeastern Cuba. Chemical Geology 213, 307-324.

Sánchez Martínez, S., Arenas, R., Andonaegui, P., Martínez Catalán, J.R. Pearce, J.A., 2007a. Geochemistry of two associated ophiolites from the Cabo Ortegal Complex (Variscan belt of northwest Spain), in: Hatcher, R.D.Jr., Carlson, M.P., McBride,J.H., Martínez Catalán, J.R. (Eds.), 4D framework of Continental Crust. Geological Society of America Memoir 200, pp. 445-477.

Sánchez Martínez, S., Arenas, R., Díaz García, F., Martínez Catalán, J.R., Gómez Barreiro, J., Pearce, J., 2007a. Careón ophiolite NW Spain: suprasubduction zone setting for the youngest Rheic Ocean floor. Geology 33, 53-56.

Santos, J.F., Schärer, U., Gil Ibarguchi, J.L, Girardeau, J., 2002. Genesis of pyroxenite-rich peridotite at Cabo Ortegal ( $\mathrm{Nw}$ Spain): geochemical and $\mathrm{Pb}-\mathrm{Sr}-\mathrm{Nd}$ isotope data Journal of Petrology 43, 17-43.

Santos Zalduegui, J.F., Schärer, U., Gil Ibarguchi, J.L, 1995. Isotope constrains on the age and origin of magmatism and metamorphism in the Malpica-Tuy allocthon, Galicia, NW-Spain. Chemical Geology 121, 91-103.

Stacey, J.S., Kramers, J.D., 1975. Approximation of terrestrial lead isotope evolution by a two-stage model. Earth and Planetary Science Letters 26, 207-221.

Tatsumi, Y., Eggins, S., 1995. Subduction Zone Magmatism. Blackwell Science.

Williams, I.S., 1998. U-Th-Pb geochronology byion microprobe: not just ages but histories Economic Geology 7, 1-35.

Wood,D.A., 1980. The application of a Th-Hf-Tadiagram to problems of tectonomagmatic classification and to establishing the nature of crustal contamination of basaltic lavas of the British Tertiary volcanic province. Earth and Planetary Science Letters 50, $11-30$

Woodhead, J.D., Eggins, S.M., Johnson, R.W., 1998. Magmagenesis in the New Britain island-arc: further insights into melting and mass transfer processes. Journal of Petrology 39, 1641-1668. 